\title{
Leguminosae nas florestas estacionais do Parque Estadual do Itacolomi, Minas Gerais, Brasil: ervas, arbustos, SUBARBUSTOS, LIANAS E TREPADEIRAS ${ }^{1}$
}

\author{
Laura Cristina Pires Lima ${ }^{2}$, Flávia Cristina Pinto Garcia ${ }^{2}$ \\ \& Ângela Lúcia Bagnatori Sartori ${ }^{3}$
}

\section{Resumo}

(Leguminosae nas florestas estacionais do Parque Estadual do Itacolomi, Minas Gerais, Brasil: ervas, arbustos, subarbustos, lianas e trepadeiras) Este trabalho consiste num levantamento florístico das Leguminosae herbáceas, arbustivas, subarbustivas, lianas e trepadeiras nas florestas estacionais do Parque Estadual do Itacolomi (PEI). As coletas mensais ocorreram entre Setembro de 2004 e Novembro de 2005. A área de estudo compreendeu oito trilhas, distribuídas nas áreas de florestas estacionais submontana, montana e altimontana. Este estudo taxonômico resultou na amostragem de 30 táxons, subordinados a 20 gêneros, os quais se distribuem entre as três subfamílias, destacando-se Papilionoideae como a de maior riqueza, tanto em número de gêneros (12) quanto de espécies (18). O gênero mais representativo foi Senna com três espécies, seguido por Bauhinia, Acacia, Inga, Piptadenia, Crotalaria, Dalbergia, Desmodium e Machaerium, todos com duas. Calliandra, Mimosa, Aeschynomene, Chaetocalyx, Camptosema, Clitoria, Dioclea, Indigofera, Poiretia, Trifolium e Vigna apresentaram apenas uma espécie. São fornecidos chave de identificação, descrições, ilustrações e comentários sobre fenologia, taxonomia e distribuição geográfica dos táxons.

Palavras-chave: Leguminosas, florística, taxonomia, levantamento, distribuição geográfica.

\section{Abstract}

(Leguminosae in the seasonal forests of the Itacolomi Park State, Minas Gerais, Brazil: herbs, shrubs, subshrubs, lianas and vines) The taxonomic study of herbaceous, shrubby and climibing members of the Leguminosae in seasonal forests of the Itacolomi State Park (PEI) was based on monthly collections from September 2004 to November 2005. The study area included eight trails, distributed in submontane, montane and upper montane seasonal forests, where 30 species distributed in 20 genera were found. Of the three subfamilies represented, subfamily Papiliononideae was the richest both in terms of genera (12) and species (18). The most representative genus was Senna with three species, followed by Bauhinia, Acacia, Inga, Piptadenia, Crotalaria, Dalbergia, Desmodium and Machaerium with two species each. Calliandra, Mimosa, Aeschynomene, Chaetocalyx, Camptosema, Clitoria, Dioclea, Indigofera, Poiretia, Trifolium and Vigna were represented by just one species. Identification key, descriptions, illustrations and comments about phenology, taxonomy and distribution are provided.

Key words: Legumes, floristic, taxonomy,survey, distribution.

\section{INTRODUÇÃO}

Leguminosae é a terceira maior família de Angiospermae e compreende cerca de 727 gêneros e 19.325 espécies (Lewis et al. 2005). No Brasil, encontram-se ca. 2.100 espécies nativas reunidas em 188 gêneros e distribuídas em quase todas as formações vegetacionais (Barroso et al. 1991; Lima 2000). Além disso, trabalhos florísticos indicam Leguminosae como uma das mais representativas em formações florestais (Oliveira-Filho et al. 1994; Ribeiro 1998; Lima 2000).
No estado de Minas Gerais, a floresta atlântica ocorre na porção centro-oriental, principalmente na região da Zona da Mata (Martins 2000) e compreende diferentes formações florestais: ombrófila mista, ombrófila densa e estacional semidecidual, sendo que esta última ocupa grande parte do território do estado (Silva 2000).

Os dados científicos disponíveis sobre as florestas estacionais se referem principalmente aos estudos fitossociológicos do componente arbóreo, resultando em uma escassez sobre

Artigo recebido em 07/2006. Aceito para publicação em 04/2007.

${ }^{1}$ Parte da dissertação de mestrado da primeira autora. Curso de Pós-Graduação em Botânica da Universidade Federal de Viçosa, Viçosa, MG, Brasil.

${ }^{2}$ Departamento de Biologia Vegetal da Universidade Federal de Viçosa, 36571-000, MG, Brasil. lcplima@yahoo.com.br ${ }^{3}$ Departamento de Biologia da Universidade Federal de Mato Grosso do Sul, Laboratório de Botânica, Cx.Postal 549, 79070-900, Campo Grande, MS, Brasil. 
os demais componentes da comunidade florestal. Além disso, estudos taxonômicos sobre Leguminosae nas florestas estacionais de Minas Gerais são escassos diante da representatividade desta família. Até o presente, Leguminosae foi avaliada em Minas Gerais, nas florestas estacionais, apenas na Estação Biológica de Caratinga (MendonçaFilho 1996) e no Parque Estadual do Rio Doce (Bortoluzzi et al. 2003; Nunes 2003; Bosquetti 2004; Bortoluzzi et al. 2004).

O Parque Estadual do Itacolomi (PEI) que está localizado nos municípios de Ouro Preto e Mariana, na região extremo oeste da floresta atlântica, na zona de transição entre os domínios da referida floresta e do cerrado (Peron 1989), apresenta sua vegetação composta por campos rupestres e florestas estacionais semideciduais montanas, de acordo com a classificação de Veloso et al. (1991).

Messias et al. (1997), em um inventário florístico de todas as famílias do PEI, encontraram 38 espécies de Leguminosae. No entanto, Dutra et al. (2006), estudando somente as Papilionoideae nos campos ferruginosos, amostraram 20 espécies, e nos campos rupestres, foram 46 espécies de Leguminosae (Dutra 2005), indicando que a família havia sido subamostrada por Messias et al. (1997). Nesses trabalhos não foram incluídas as espécies das florestas estacionais, que constituem a maior área da cobertura vegetal do PEI.

O presente estudo teve como objetivo realizar um levantamento florístico dos táxons de Leguminosae herbáceos, arbustivos, subarbustivos, lianas e trepadeiras, nas florestas estacionais do PEI, com o fornecimento de chave de identificação, descrições e ilustrações para identificação das espécies estudadas; distribuição geográfica, preferência por habitats e comentários taxonômicos.

\section{Material e Métodos}

\section{Área de estudo}

O Parque Estadual do Itacolomi (PEI) foi criado pelo decreto $n^{\circ} 4465$ de 19 de junho de 1967 e está localizado entre os meridianos $43^{\circ} 32^{\prime}$ e $43^{\circ} 22^{\prime} \mathrm{W}$ e os paralelos $20^{\circ} 30^{\prime}$ e 20²0’ S, nos municípios de Ouro Preto e Mariana, em Minas Gerais (Messias et al. 1997). Os tipos de solos ocorrentes no PEI são: arenoso claro, associado ao quartzito e argiloso, no qual predomina latossolo vermelho-amarelo, sendo este o mais comum em áreas de vegetação florestal (Messias et al. 1997). O clima regional é caracterizado, segundo a classificação de Koeppen como Cwb, úmido (mesotérmico), ou seja, temperado úmido com inverno seco e verão quente chuvoso (Messias et al. 1997). A pluviosidade é de, aproximadamente, $2.000 \mathrm{~mm}$ anuais, com concentração de chuvas no período de outubro a março e seca no período de abril a agosto, o que é uma característica típica de floresta estacional (Messias et al. 1997).

A vegetação do PEI está composta por duas formações vegetacionais: os campos e as florestas, cada uma delas apresentando variação de acordo com o solo, disponibilidade de água, altitude e relevo. Os campos ocupam a maior extensão da área do Parque, entremeados com áreas de florestas, formando capões de extensão variável (Messias et al. 1997). As florestas do PEI podem ser denominadas como: pluvial ripária e pluvial baixo-montana (Rizzini 1997). De acordo com a classificação de Veloso et al. (1991), podem ser consideradas como florestas estacionais semideciduais montanas (acima de $550 \mathrm{~m}$ de altitude). Utilizando-se a classificação de Oliveira-Filho \& Fontes (2000) as florestas estacionais podem ser: submontana entre 300$700 \mathrm{~m}$ de altitude, montana entre 700-1100 m de altitude e altimontana acima de $1100 \mathrm{~m}$ de altitude. Esta última classificação é adotada neste trabalho.

\section{Coleta e tratamento taxonômico}

As coletas foram realizadas mensalmente, de setembro/2004 a novembro/2005, ao longo de oito trilhas (Fig. 1): 1. Alcan; 2. Estrada de Baixo; 3.Forno; 4. Estrada da Torre; 5. Baú; 6. Custódio; 7. Belém; 8. Cibrão. Nesta última trilha as espécies foram coletadas ao longo do 


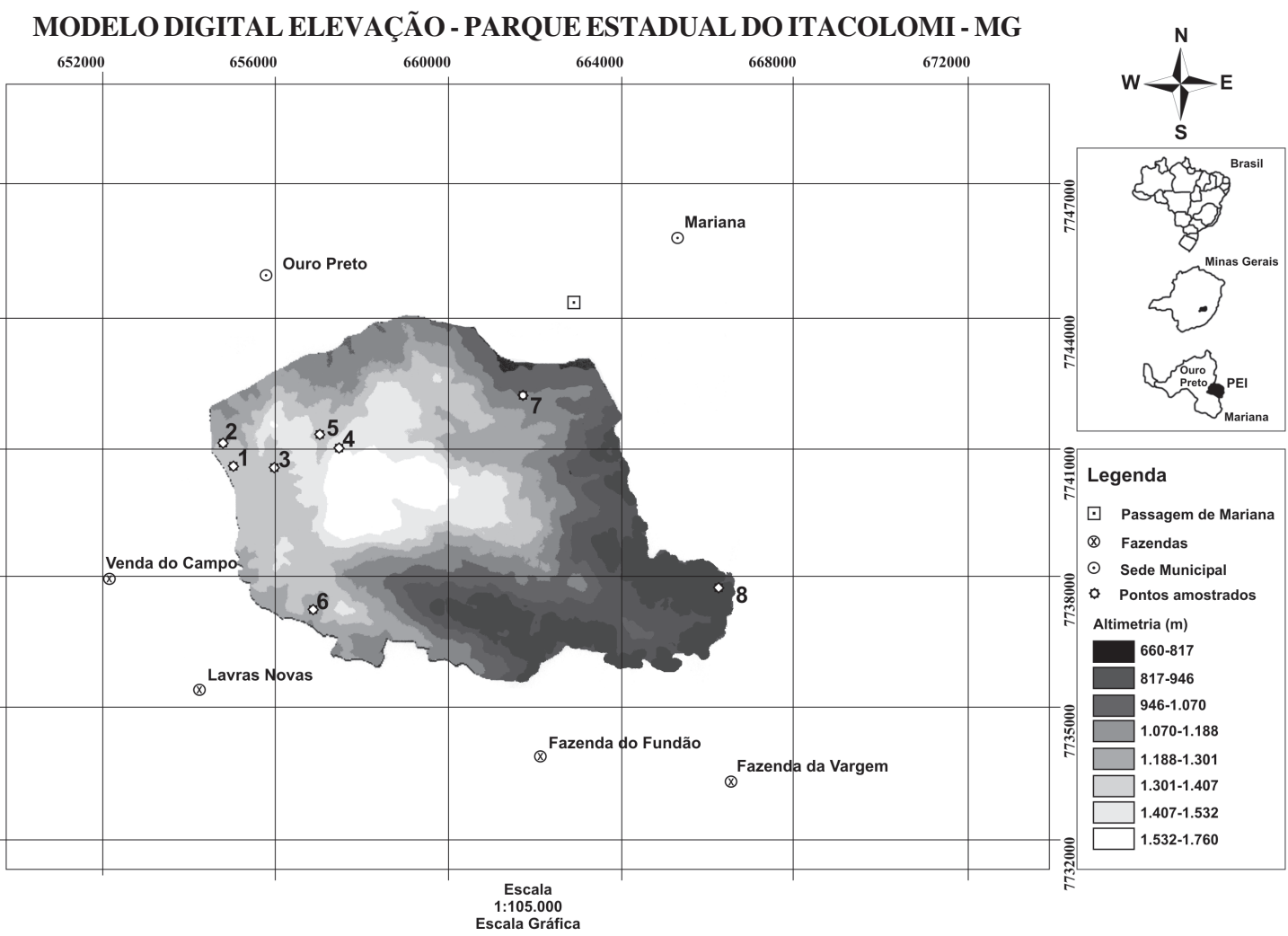

Figura 1 - Localização do Parque Estadual do Itacolomi e áreas estudadas. 1. Alcan; 2. Estrada de Baixo; 3. Forno; 4. Estrada da Torre; 5. Baú; 6. Custódio; 7. Belém; 8. Cibrão.

rio Mainarte. O material botânico foi coletado conforme as técnicas de Fidalgo \& Bononi (1984), registrado e incorporado no acervo do herbário VIC, duplicatas foram enviadas ao herbário OUPR.

A identificação das espécies foi realizada por meio de literatura taxonômica, comparação com coleções dos herbários OUPR, BHCB, VIC (siglas conforme Holmgren et. al. 1990) e consulta a especialistas. A classificação adotada para subfamílias, tribos e gêneros segue Lewis et al. (2005).

Para caracterização dos tipos de hábito foi adotada a terminologia de Guedes-Bruni et al. (2002) com algumas adaptações, sendo consideradas: ervas, plantas não lenhosas com até $50 \mathrm{~cm}$ alt.; subarbustos, plantas eretas com ramificação próxima do chão, cujos ramos são parcialmente lignificados; arbustos, plantas ramificadas a partir de $1 \mathrm{~m}$ alt. e com ramos lenhosos; trepadeiras, plantas com ramos flexíveis não lenhosos que apoiam-se em árvores ou arbustos; e lianas, trepadeiras com caule lenhoso. A terminologia utilizada para a descrição das estruturas vegetativas e reprodutivas está de acordo com Radford et al. (1974), Harris \& Harris (1994) e Barroso et al. (1999).

\section{Resultados e Discussão}

O estudo taxonômico das espécies de Leguminosae herbáceas, subarbustivas, arbustivas, trepadeiras e lianas, ocorrentes nas florestas estacionais do PEI, totalizou 30 espécies reunidas em 20 gêneros, agupados em 11 tribos. Os gêneros mais representaivos foram Senna com três espécies, Bauhinia, Acacia, Inga, Piptadenia, Crotalaria, Dalbergia e Machaerium, todos com duas; e os demais gêneros Calliandra, Mimosa, Aeschynomene, Chaetocalyx, Camptosema, Clitoria, Dioclea, Indigofera, Poiretia, Trifolium e Vigna, com uma espécie. 
Chave de identificação dos táxons de Leguminosae das florestas estacionais do PEI: ervas, arbustos, subarbustos, lianas e trepadeiras

1. Folhas 1-folioladas ou 3-folioladas.

2. Folhas 1-folioladas.

3. Caule alado; folíolo não bilobado; anteras heteromorfas; legume inflado.

4. Ramos velutinos ou vilosos; folíolo elíptico ou oblongo ... 18. Crotalaria breviflora

4'. Ramos glabros; folíolo obovado 19. Crotalaria paulina

3'. Caule não alado; folíolo bilobado; anteras uniformes; legume plano-compresso.

5. Pecíolo até 1,5 cm compr.; folíolo 7-nervado, base obtusa ou truncada; nectário foliar presente; legume não samaróide .... 2. Bauhinia ungulata var. cuiabensis

5'. Pecíolo maior que $4 \mathrm{~cm}$ compr.; folíolo 9-11-nervado, base cordada; nectário foliar ausente; legume samaróide .

1. Bauhinia leiopetala

2'. Folhas 3-folioladas.

6. Ervas ou subarbustos.

7. Folíolo terminal com margem inteira; estipela presente; inflorescência pseudoracemosa ou paniculada; estames diadelfos.

8. Estipela 1-2 mm compr.; raque foliar serícea ou tomentosa; folíolo terminal obovado ou orbicular; lomento 1-2 articulado; artículo 0,8-1,4 cm compr. .

22. Desmodium adscendens

8'. Estipela 5-7 mm compr.; raque foliar hirsuta; folíolo terminal ovadolanceolado; lomento 3-8 articulado; artículo 2,5-4 cm compr.

23. Desmodium uncinatum

7'. Folíolo terminal com margem serrilhada; estipela ausente; inflorescência umbelada; estames monadelfos

29. Trifolium repens

6'. Trepadeiras ou lianas.

9. Lianas ....

24. Dioclea violacea

9'. Trepadeiras.

10. Folíolos laterais simétricos; flores não ressupinadas e pétalas da carena retas

15. Camptosema bellum

10'. Folíolos laterais assimétricos; flores ressupinadas ou pétalas da carena contorcidas.

11. Ramos hirsutos; estipela ovado-lanceolada; corola branca; ovário puberulento; estilete reto, ciliado ...... 17. Clitoria falcata var. falcata

11'. Ramos glabrescentes ou seríceos; estipela oblonga; corola lilásarroxeada; ovário tomentoso; estilete espiralado, hirsuto .

1'. Folhas plurifolioladas.

30. Vigna peduncularis var. peduncularis

12. Folhas pinadas.

13. Nectário foliar presente.

14. Raque foliar canaliculada ou estriada; corola dialipétala; androceu dialistêmone; estaminódios presentes.

15. Folhas 6-10-folioladas; corola 20-23 mm compr.; estigma terminal.

16. Estípula linear; nectário entre o $1^{\circ}$ par de folíolos; sépalas obovadas; ovário tomentoso.

3. Senna pendula var. glabrata

16'. Estípula reniforme; nectários entre todos os pares de folíolos; sépalas oblongas; ovário pubescente

5. Senna reniformis

15'. Folhas 16-folioladas; corola 13-15 mm compr.; estigma lateral

4. Senna pneumatica 
14'. Raque foliar marginada ou alada; corola gamopétala; androceu monadelfo; estaminódios ausentes.

17. Folhas 6-8-folioladas; face abaxial do folíolo hirsuta; filetes róseos; fruto tomentoso

10. Inga vulpina

17'. Folhas (14-)16-28-folioladas; face abaxial do folíolo glabra; filetes brancos; fruto glabro

9. Inga schinifolia

13'. Nectário foliar ausente.

18. Folhas paripinadas.

19. Ramos estriados, hirsutos; folíolos com pontuações translúcidas na face abaxial; estipela presente 28. Poiretia punctata

19'. Ramos cilíndricos, seríceos; folíolos sem pontuações translúcidas na face abaxial; estipela ausente 14. Aeschynomene elegans var. elegans

18 '. Folhas imparipinadas.

20. Estipela presente.

21. Trepadeiras; folhas 5-folioladas; corola amarela; estames monadelfos . ....

16. Chaetocalyx longiflora

21'. Arbustos; folhas 11-15-folioladas; corola coral; estames diadelfos

25. Indigofera suffruticosa

20'. Estipela ausente.

22. Ramos ou gavinhas aculeados; sâmara com região seminífera basal.

23. Ramos com gavinhas; folhas 5-7-folioladas; estípula 1,5 mm compr., não espinescente, triangular; folíolos oblongos, obovados, raro elípticos; sâmara oblonga

27. Machaerium oblongifolium

23'. Ramos sem gavinhas; folhas 31-39-folioladas; estípula 4 mm compr., espinescente, unciforme; folíolos oblongos; sâmara falcada

26. Machaerium aculeatum

22'. Ramos inermes; sâmara com região seminífera central.

24. Folhas 7-11(-17)-folioladas; folíolos ovados ou elípticos, face abaxial puberulenta 21. Dalbergia frutescens var. frutescens

24'. Folhas 17-29-folioladas; folíolos lanceolados ou oblongos, face abaxial serícea

20. Dalbergia brasiliensis

12'. Folhas bipinadas.

25. Nectário foliar presente.

26. Inflorescência espiciforme; androceu 10 estames; anteras glandulares na antese.

27. Folhas (3-)4-6 pinadas; foliólulos 4-6 pares, obovados

12. Piptadenia adiantoides

27’. Folhas 8-15 pinadas; foliólulos 30-49 pares, lineares ou linear-falcados 13. Piptadenia micracantha

26'. Inflorescência capituliforme; androceu com mais de 10 estames; anteras eglandulares na antese.

28. Ramos glabrescentes; folhas 6-10-pinadas, foliólulos acima de 6,1 mm compr.

7. Acacia aff. riparia

28'. Ramos tomentosos; folhas 15-23-pinadas; foliólulos até 3,5 mm compr.

6. Acacia martiusiana

25'. Nectário foliar ausente.

29. Ramos armados; inflorescência homomórfica; corola tetrâmera; estames livres. fruto craspédio 11. Mimosa bimucronata var. bimucronata

29'. Ramos inermes; inflorescência heteromórfica; corola pentâmera ou hexâmera; estames monadelfos; fruto legume 8. Calliandra parvifolia 


\section{Caesalpinioideae}

1. Bauhinia leiopetala Benth., Fl. bras. 12(20): 210. 1870.

Fig. $2 \mathrm{a}-\mathrm{b}$

Liana, ramo estriado, glabro ou glabrescente, não alado. Estípula 3-6 mm compr., lanceolada, caduca; pecíolo 4-8 cm compr.; raque ausente, nectário ausente. Folha 1-foliolada; folíolo bilobado 7,5-10×10-10,3 cm, lobo 4,4$5 \times 3,2-4,3 \mathrm{~cm}$, ápice acuminado, base cordada, face adaxial glabra, abaxial serícea, 9-11nervado. Inflorescência espiciforme, terminal; pedúnculo 0,7-2,1 cm compr., ferrugíneotomentoso; raque 4,1-9 cm compr., ferrugíneatomentosa. Flor pentâmera, actinomorfa, séssil; cálice $6 \mathrm{~mm}$ compr., gamossépalo, campanulado, glabro externamente; corola $10 \mathrm{~mm}$ compr., branca e rósea, pétalas oblanceoladas; estames 10, isodínamos, dialistêmones, filetes 10-11 mm compr., glabros, anteras uniformes $2-3 \mathrm{~mm}$ compr., estaminódios ausentes; ovário $4 \mathrm{~mm}$ compr., seríceo, estípite 1-2 mm compr.; estilete $6 \mathrm{~mm}$ compr., nutante, seríceo; estigma terminal, glabro. Legume samaróide, $8-13 \times 1,4-1,5 \mathrm{~cm}$, plano compresso, glabro, indeiscente; semente $1,1,2 \times 1 \mathrm{~cm}$, arredondada, castanha.

Material examinado: trilha de Belém, 17.VI.2005, st., L. C. P. Lima et al. 407 (VIC).

Material adicional examinado: BRASIL. MINAS GERAIS: Marliéria, entorno do Parque Estadual do Rio Doce, 6.VI.2003, fl., L. Bosquetti \& W. Queiroga 151 (VIC); Santa Bárbara, Cenibra, 15.VII.1992, fr., S. Costa s.n. (BHCB 22309).

Bauhinia leiopetala é diferenciada das outras espécies de Bauhinia ocorrentes no PEI pelo hábito escandente e os folíolos de base cordada. Na Flora brasiliensis, Bentham (1870) observou uma forte afinidade entre Bauhinia radiata Vell. e B. leiopetala. Vaz (com. pess.) apontou a necessidade de revisão destes táxons que possivelmente podem ser formas distintas da mesma espécie. Ocorre somente no Brasil, onde pode ser encontrada nos estados de Pernambuco, Bahia, Minas Gerais e Rio de Janeiro (Vaz 1995). Segundo esta mesma autora, B. leiopetala, tem preferência por florestas submontanas no estado do Rio de Janeiro. No PEI, foi coletada em floresta estacional montana.
2. Bauhinia ungulata var. cuiabensis (Bong.) Vaz, Rodriguésia 54(83): 55-143. 2003.

Fig. 2 c-e

Arbusto 2-3 m alt., ramo estriado, ferrugíneo-puberulento, caule não alado. Estípula $2 \mathrm{~mm}$ compr., lanceolada, caduca; pecíolo $(0,7-) 0,8-1(-1,5) \mathrm{cm}$ compr.; raque ausente; nectário intra-estipular, rudimentar. Folha 1-foliolada; folíolo bilobado 2,5-6,8 $\times 2,5-$ $6,8 \mathrm{~cm}$, lobo $1-2,5 \times 1,1-3 \mathrm{~cm}$, ápice agudo ou obtuso, base obtusa ou truncada, face adaxial glabra, face abaxial ferrugíneo-pubescente, 7 nervado. Inflorescência pseudo-racemosa, terminal; pedúnculo 1,5-1,8 cm compr., ferrugíneo-pubescente; raque 6-9 cm compr., ferrugínea-pubescente. Flor pentâmera, zigomorfa, pedicelada; cálice 15-18 mm compr., gamossépalo, tubuloso, ferrugíneopuberulento externamente; corola $47-73 \mathrm{~mm}$ compr., branca, pétalas linear-lanceoladas; estames 10, heterodínamos, monadelfos, filetes livres 32-54 mm compr., glabros, anteras uniformes 7-9 mm compr., estaminódios 2; ovário 10-15 mm compr., puberulento, estípite $20 \mathrm{~mm}$ compr.; estilete $42 \mathrm{~mm}$ compr., curvado, glabro; estigma terminal, glabro. Legume, $8-$ $13 \times 1,4-1,5 \mathrm{~cm}$, plano-compresso, puberulento, deiscente; sementes 10-12, $8 \times 6 \mathrm{~mm}$, arredondadas, castanhas.

Material examinado: estrada do Cibrão, 7.XII.2004, fr., L. C. P. Lima \& M. E. F. Araújo 249 (VIC); trilha de Belém, 26.IV.2005, fl., L. C. P. Lima et al. 340 (VIC); 17.VI.2005, fr., L. C. P. Lima et al. 372 (VIC).

O número de nervuras do folíolo e a forma das pétalas são características diagnósticas desta Bauhinia ungulata (Vaz \& Tozzi 2003). Segundo essas mesmas autoras, a espécie possui três variedades com registros para as Regiões Centro-Oeste e Sudeste do Brasil: $B$. ungulata var. cuiabensis, B. ungulata var. ungulata $\mathrm{L}$. e $B$. ungulata var. parvifolia (Ducke) Vaz. B. ungulata var. cuiabensis difere das outras pelos folíolos cartáceos ou coriáceos, menores que 7,5 cm compr. Ocorre no Paraguai e Brasil, onde pode ser encontrada nos estados da Bahia, Minas Gerais, Rio de Janeiro, São Paulo, Distrito Federal, Goiás, Mato Grosso, Mato Grosso do Sul e Tocantins, 


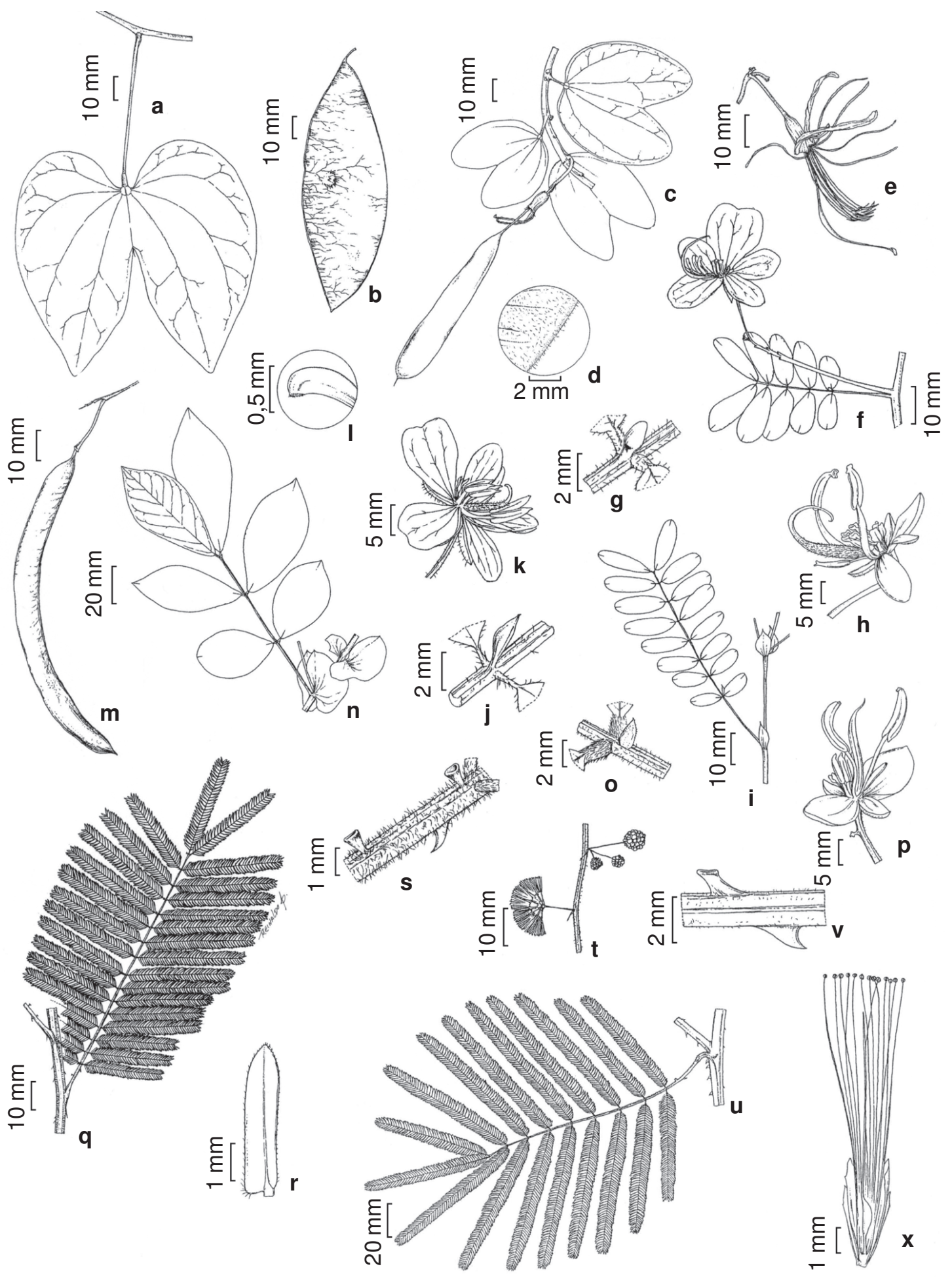

Figura 2 - a-b. Bauhinia leiopetala - a. folha (Lima 407); b. fruto (Costa s.n. BHCB 22309). c-e. B. ungulata var. cuiabensis - c. ramo com fruto; d. detalhe do indumento do fruto (Lima 372); e. flor (Lima 340). f-h. Senna pendula var. glabrata - f. ramo com inflorescência; g. nectário; h. flor sem pétalas (Lima 349). i-m. S. pneumatica - i. folha; j. nectário; k. flor; l. estigma; m. fruto (Lima 293). n-p. S. reniformis - n. ramo; o. nectário (Lima 333); p. flor sem pétalas (Lima 232). q-t. Acacia martiusiana - q. folha; r. foliólulo; s. nectário e acúleo; t. detalhe da inflorescência (Lima 304). u-x. A. aff. riparia - u. folha; v. nectário e acúleo; x. flor em corte longitudinal (Lima 288). 
habitando cerrado, cerradão, campo cerrado, campo sujo, campo úmido, formações do pantanal, carrasco, caatinga, florestas de galeria, florestas abertas, florestas semidecíduas e na zona de transição floresta-cerrado (Vaz \& Tozzi 2003). No PEI, foi coletada em áreas de floresta submontana e montana.

3. Senna pendula var. glabrata (Vogel) H.S. Irwin \& Barneby, Mem. New York Bot. Gard. 35(1): 382. 1982.

Fig. 2 f-h

Arbusto $2 \mathrm{~m}$ alt., ramo estriado, tomentoso. Estípula $2 \mathrm{~mm}$ compr., linear, caduca; pecíolo 2,3-2,8 cm compr.; raque 2-3 cm compr., estriada; nectário entre o primeiro par de folíolos, subssésil, globoso. Folha 8-10foliolada, paripinada; folíolos 2,8-3,4×1-1,3 $\mathrm{cm}$, opostos, obovados, base oblíqua, ápice obtuso ou acuminado, ambas as faces glabras, pubescente na nervura principal. Inflorescência racemosa, axilar; pedúnculo $2-2,7 \mathrm{~cm}$ compr., glabrescente; raque $0,8-1 \mathrm{~cm}$ compr., glabrescente. Flor pentâmera, zigomorfa, pedicelada; cálice $11 \mathrm{~mm}$ compr., dialissépalo, sépalas obovadas, hirsutas externamente; corola dialipétala, $23 \mathrm{~mm}$ compr., amarela, pétala centro-adaxial suborbicular; estames 7 , heterodínamos, dialistêmones, filetes 2-20 mm compr., glabros, anteras 6-10 mm compr., estaminódios 3; ovário $13 \mathrm{~mm}$ compr., tomentoso, estípite $2 \mathrm{~mm}$ compr.; estilete $6 \mathrm{~mm}$ compr., curvado, glabro; estigma terminal, glabro. Legume bacóide, 14-16 × 1-1,5 cm, subcilíndrico, glabro, indeiscente; sementes 3254 , oblongas, enegrecidas.

Material examinado: Calais, 17.VI.2004, fr., V. F. Dutra \& O. L. Pereira 212 (VIC); estrada de Baixo, 28.IV.2005, fl., L. C. P. Lima \& E. D. Silva 349 (VIC).

O número de jugas (4-5) e os estames centro-adaxiais pêndulos são diagnósticos de Senna pendula (Irwin \& Barneby 1982). No PEI, Senna pneumatica também possui folíolos obovados, sendo semelhante aos de $S$. pendula var. glabrata, entretanto o número de folíolos e a forma da estípula são características vegetativas que diferenciam estes táxons. Distribui-se no centro-oeste, nos estados da Bahia, São Paulo, Paraná e
Santa Catarina, ocupando orlas florestais antropizadas, em altitudes com ca. $700 \mathrm{~m}$, bem como ambientes abertos, barrancos, em beira de estradas e rodovias (Irwin \& Barneby 1982). No PEI, foi coletada em floresta estacional altimontana.

4. Senna pneumatica H.S. Irwin \& Barneby, Mem. New York Bot. Gard. 35(1): 329. 1982.

Fig. 2 i-m

Arbusto 1,5 m alt., ramo estriado, tomentoso. Estípula 9-15 mm compr., ovada, persistente; pecíolo 2,4-3,5 cm compr.; raque 6,5-9 cm compr., estriada; nectário entre o primeiro par de folíolos, estipitado, cilíndrico. Folha 16-foliolada, paripinada; folíolos 2-3× 0,6-1 cm, opostos, obovados, base oblíqua, ápice mucronado, face adaxial glabra, face abaxial pubescente, principalmente na nervura principal. Inflorescência racemosa, terminal; pedúnculo $2,2-2,5 \mathrm{~cm}$ compr., pubérulo; raque 1,2-1,5 cm compr., pubérula. Flor pentâmera, zigomorfa, pedicelada; cálice $8 \mathrm{~mm}$ compr., dialissépalo, sépalas ovadas, hirsutas externamente; corola dialipétala, 13-15 mm compr., amarela, pétala centro adaxial orbicular; estames 7, heterodínamos, dialistêmones, filetes 4-6 mm compr., glabros, anteras 5-6 mm compr., estaminódios 3; ovário $5 \mathrm{~mm}$ compr., seríceo, estípite $1 \mathrm{~mm}$ compr.; estilete $4 \mathrm{~mm}$ compr., curvado, glabro; estigma lateral, ciliado. Legume, 9-9,5 $\times 0,8 \mathrm{~cm}$, plano compresso, glabro ou glabrescente, deiscente; sementes $15-16,6-7 \times 4-5 \mathrm{~mm}$, obovadas, castanho claras.

Material examinado: trilha do Baú, 3.VIII.2004, fr., L. C. P. Lima et al. 208 (VIC); 16.II.2005, fl., fr., L. C. P. Lima \& S. C. Ferreira 293 (VIC).

No PEI, S. pneumatica é facilmente reconhecida entre as espécies do gênero pela estípula ovada e oito pares de folíolos. É uma espécie próxima de $S$. organensis (Harms) H.S. Irwin \& Barneby, da qual se diferencia pela forma e comprimento do fruto (Irwin \& Barneby 1982). Até então, restrita à Serra de Caparaó, no estado de Minas Gerais limite com o Espírito Santo. Nas matas do PEI, foi coletada em floresta estacional altimontana. 
5. Senna reniformis (G.Don) H.S.Irwin \& Barneby, Mem. New York Bot. Gard. 35(1): 223. 1982.

Fig. 2 n-p

Arbusto ou arvoreta 1,5-5 m alt., ramo estriado, glabrescente ou tomentoso. Estípula 1,4-3,1 mm, reniforme, persistente; pecíolo $1,5-2,5 \mathrm{~cm}$ compr.; raque $2,8-5 \mathrm{~cm}$ compr., canaliculada; nectários entre todos os pares de folíolos, séssil, piriforme. Folha 6-foliolada, paripinada; folíolos 6,7-9,5 × 2,8-3,7 cm, opostos, oblongos ou obovados, base obtusa, ápice agudo, face adaxial glabra e face abaxial glabrescente ou tomentosa, principalmente na nervura principal. Inflorescência racemosa, axilar ou terminal; pedúnculo 2-3,7 cm compr., tomentoso; raque $2-4 \mathrm{~cm}$ compr., tomentosa. Flor pentâmera, zigomorfa, pedicelada; cálice $10 \mathrm{~mm}$ compr., dialissépalo, sépalas oblongas, glabras externamente; corola dialipétala, $20 \mathrm{~mm}$ compr., amarela, pétala centro adaxial obovada; estames 7 , heterodínamos, dialistêmones, filetes $7-25 \mathrm{~mm}$ compr., glabros, anteras $3 \mathrm{~mm}$ compr., estaminódios 3; ovário $18 \mathrm{~mm}$ compr., pubescente, estípite $4 \mathrm{~mm}$ compr.; estilete $1 \mathrm{~mm}$ compr., curvado, glabro; estigma terminal, glabro. Legume, $9-12 \times 1-2 \mathrm{~cm}$, plano compresso, glabro, deiscente; sementes 24-28, $6 \times 5 \mathrm{~mm}$, oblongas, enegrecidas.

Material examinado: Cibrão, 27.IV.2005, fl., L. C. P. Lima et al. 347 (VIC); estrada em direção a Torre, 6.XII.2004, fl. e fr., L. C. P. Lima \& O. Magalhães 232 (VIC); trilha Alcan, 25.IV.2005, fl., L.C.P. Lima \& E. D. Silva 333 (VIC); trilha de Belém, 7.XII.2005, fl. e fr., L. C. P. Lima \& M. E. F. Araújo 235 (VIC).

É uma espécie próxima de Senna cana (Nees \& C. Mart.) H.S. Irwin \& Barneby, da qual difere pela localização dos nectários entre todos os pares de folíolos e do fruto plano compresso. Distribui-se nos estados de Minas Gerais e Bahia, sendo endêmica da Cadeia do Espinhaço, onde habita cerrado, margem de mata de galeria, brejo e vegetações com altitudes entre 950 e $1.800 \mathrm{~m}$ (Irwin \& Barneby 1982). Nas matas do PEI, foi coletada em floresta estacional altimontana, e observada em floresta estacional montana e submontana.

\section{Mimosoideae}

6. Acacia martiusiana (Steud.) Burkart, Fl. Il. Catarin. 30: 1979.

Fig. $2 \mathrm{q}-\mathrm{t}$

Liana armada, ramo estriado, ferrugíneotomentoso, acúleos recurvos. Estípula não observada, caduca; pecíolo 0,9-1,6 cm compr ferrugíneo-tomentoso; raque $3,5-16,5 \mathrm{~cm}$ compr., canaliculada, aculeada, ferrugíneotomentosa; nectário estipitado, cupuliforme, no pecíolo, entre o par de pina proximal e os pares distais. Folha bipinada, pinas 15-23 pares; foliólulos 42-58 pares, 3,1-3,5 ×0,5-0,8 mm, opostos, oblongos, base oblíqua, ápice acuminado, ambas as faces glabras, ciliado. Inflorescência capituliforme reunida em panícula terminal, homomórfica; pedúnculo 8$12 \mathrm{~mm}$ compr., ferrugíneo-tomentoso; raque globosa, diâmetro da inflorescência 6-8 mm (excluindo os filetes). Flor pentâmera, actinomorfa, séssil; cálice $2 \mathrm{~mm}$ compr., campanulado, pubescente externamente; corola gamopétala, 3,5 $\mathrm{mm}$ compr., glabrescente externamente; estames 70-73, filetes brancos, livres, 5-7 mm compr., glabros, anteras eglandulares; ovário $1 \mathrm{~mm}$ compr., glabro ou puberulento, estípite $1 \mathrm{~mm}$ compr.; estilete 6-6,2 mm compr., glabro. Legume, 8$12,5 \times 2-2,5 \mathrm{~cm}$, plano compresso, margem inteira ou levemente sinuosa, ápice aristado, puberulento ou glabro; sementes 8-10, $10 \times 7$ $\mathrm{mm}$, arredondadas, castanhas.

Material examinado: Cibrão, 17.II.2005, fl., L. C. P. Lima et al. 304 (VIC); 16.VI.2005, fr., L. C. P. Lima et al. 368 (VIC); 18.X.2005, fr., L. C. P. Lima et al. 393 (VIC).

A coloração ferrugínea dos tricomas, 1523 pares de pinas e o nectário estipitado são característicos de Acacia martiusiana (Lima et al. 1994). Essa espécie tem sido citada por Bentham (1876) e Lewis (1987) como Acacia adhaerens Benth., que foi sinonimizada por Burkart (1979) em Acacia martiusiana. Ocorre nos estados da Bahia a Santa Catarina (Lewis 1987; Lima et al. 1994; Mendonça-Filho 1996). Espécie típica da porção sudeste sul da floresta pluvial atlântica, ocorrendo principalmente nas áreas de vegetação secundária e orla de mata (Lima et al. 1994). No PEI, foi coletada somente em floresta estacional submontana. 
7. Acacia aff. riparia Kunth., Nov. Gen. Sp. (folio ed.) 6: 218. 1824.

Fig. $2 \mathrm{u}-\mathrm{x}$

Liana armada, ramo estriado, glabrescente, acúleos recurvos. Estípula $2 \mathrm{~mm}$ compr., ovada, caduca; pecíolo $2-3,5 \mathrm{~cm}$ compr. pubescente; raque 5,5-9,5 cm compr., canaliculada, pubescente; nectário estipitado, cupuliforme, no pecíolo, entre o par de pina proximal e distal. Folha bipinada, pinas $6-10$ pares; foliólulos 40-64 pares, 6,1-10,1 × 1$1,1 \mathrm{~mm}$, opostos, oblongos, base oblíqua, ápice agudo, face adaxial glabra, abaxial serícea. Inflorescência capituliforme reunida em panícula terminal, homomórfica; pedúnculo 3-7 $\mathrm{mm}$ compr., pubescente; raque globosa, diâmetro da inflorescência 7-8 mm (excluindo os filetes). Flor pentâmera, actinomorfa, séssil; cálice 22,5 mm compr., campanulado, pubescente externamente; corola gamopétala, $3,5 \mathrm{~mm}$ compr., glabra externamente; estames 71-74, filetes brancos, livres, 5-10 mm compr., glabros, anteras eglandulares; ovário $1 \mathrm{~mm}$ compr., glabro, estípite $1 \mathrm{~mm}$ compr.; estilete $7-8 \mathrm{~mm}$ compr., glabro. Legume, $10-13 \times 2,5 \mathrm{~cm}$, plano compresso, margem reta, ápice mucronulado, pubescente; sementes $10-12,9 \times 4 \mathrm{~mm}$, obovadas, castanho-escuras.

Material examinado: trilha da Alcan, 8.XII.2004, fr., L. C. P. Lima \& M. E. F. Araújo 261 (VIC); 30.I.2005, fl., L. C. P. Lima \& S. C. Ferreira 288 (VIC).

O exemplar analisado apresenta afinidade com a descrição de A. nitidifolia Speg., porém difere no comprimento do foliólulo (até 10,1 $\mathrm{mm}$ ), ausência de hipófilo e o comprimento do fruto (acima $13 \mathrm{~cm}$ ). Com o auxílio de especialistas e a descrição de Bentham (1876), esta espécie foi identificada como $A$. aff. riparia, diferindo apenas na glândula peciolar estipitada. Devido a dificuldade de identificação do táxon e a representatividade do gênero no Brasil com ca. 100 spp. (Silva 1990), evidenciase a necessidade de revisões taxonômicas neste grupo. Existem registros de Acacia riparia para a América Central e América do Sul nos países Equador, Colômbia, Peru, Argentina, Bolívia e Brasil (Ildis 2005). No Brasil, essa espécie ocorre nos estados da Bahia, Minas Gerais, Rio de Janeiro e São
Paulo (Bentham 1876; Barroso 1965; Lewis 1987). No PEI, foi coletada apenas na trilha da Alcan, em floresta estacional altimontana.

8. Calliandra parvifolia (Hook. \& Arn.) Speg., Revista Argent. Agron. 1: 193. 1926.

Fig. 3 a-e

Arbusto ou arvoreta 1,5-5 m alt., ramo cilíndrico, glabro ou glabrescente, inerme. Estípula 3-7 mm compr., lanceolada, persistente; pecíolo $0,8-1,2 \mathrm{~cm}$ compr., tomentoso; raque 5-8,2 cm compr., canaliculada, tomentosa; nectário ausente. Folha bipinada, pinas 8-20 pares; foliólulos 30-48 pares, $2-3,5 \times 0,5-$ $0,8 \mathrm{~cm}$, opostos, oblongos, base oblíqua, ápice obtuso, margem ciliada face abaxial glabra, face adaxial tomentosa na base, ambas as faces com pontuações. Inflorescência capituliforme, axilar, heteromórfica; pedúnculo 13-16 mm compr., viloso; raque globosa, diâmetro da inflorescência 9-10 mm (excluindo filetes). Flor pentâmera ou hexâmera, actinomorfa, séssil ou pedicelada; flor periférica pentâmera, pedicelada, pedicelo $0,5-$ 0,8 mm compr.; cálice $2-2,2 \mathrm{~mm}$ compr., funiliforme, tomentoso externamente; corola gamopétala, 4-5 $\mathrm{mm}$ compr., tomentosa externamente; estames 16, filetes brancos na base e avermelhados no ápice, tubo estaminal incluso, $3 \mathrm{~mm}$ compr., filetes livres $32-35 \mathrm{~mm}$ compr., glabros, anteras eglandulares; ovário $1,2 \mathrm{~mm}$ compr., glabro, estípite $0,1 \mathrm{~mm}$ compr.; estilete $22 \mathrm{~mm}$ compr., glabro; flor terminal hexâmera, séssil; cálice $3 \mathrm{~mm}$ compr., campanulado; estames 22; estilete $38 \mathrm{~mm}$ compr. Legume, 7-11 × 0,9-1,3 cm, plano compresso, margem reta espessa, ápice caudado, glabro ou puberulento; sementes $5-10,4-5 \times 2-3 \mathrm{~mm}$, obovadas, castanhas.

Material examinado: estrada do Cibrão, 7.XII.2004, fr., L. C. P.Lima \& M. E. F.Araújo 248(VIC), 26.IX.2005, fl., L. C. P. Lima \& F. C. P. Garcia 382 (VIC). Calliandra parvifolia é diferenciada das demais espécies do PEI, pelos filetes brancos na base e avermelhados no ápice e o legume com as margens espessas. Distribui-se no Paraguai e Brasil, onde é citada para o Amazonas, Pará, Maranhão, Ceará, Bahia, Rio 

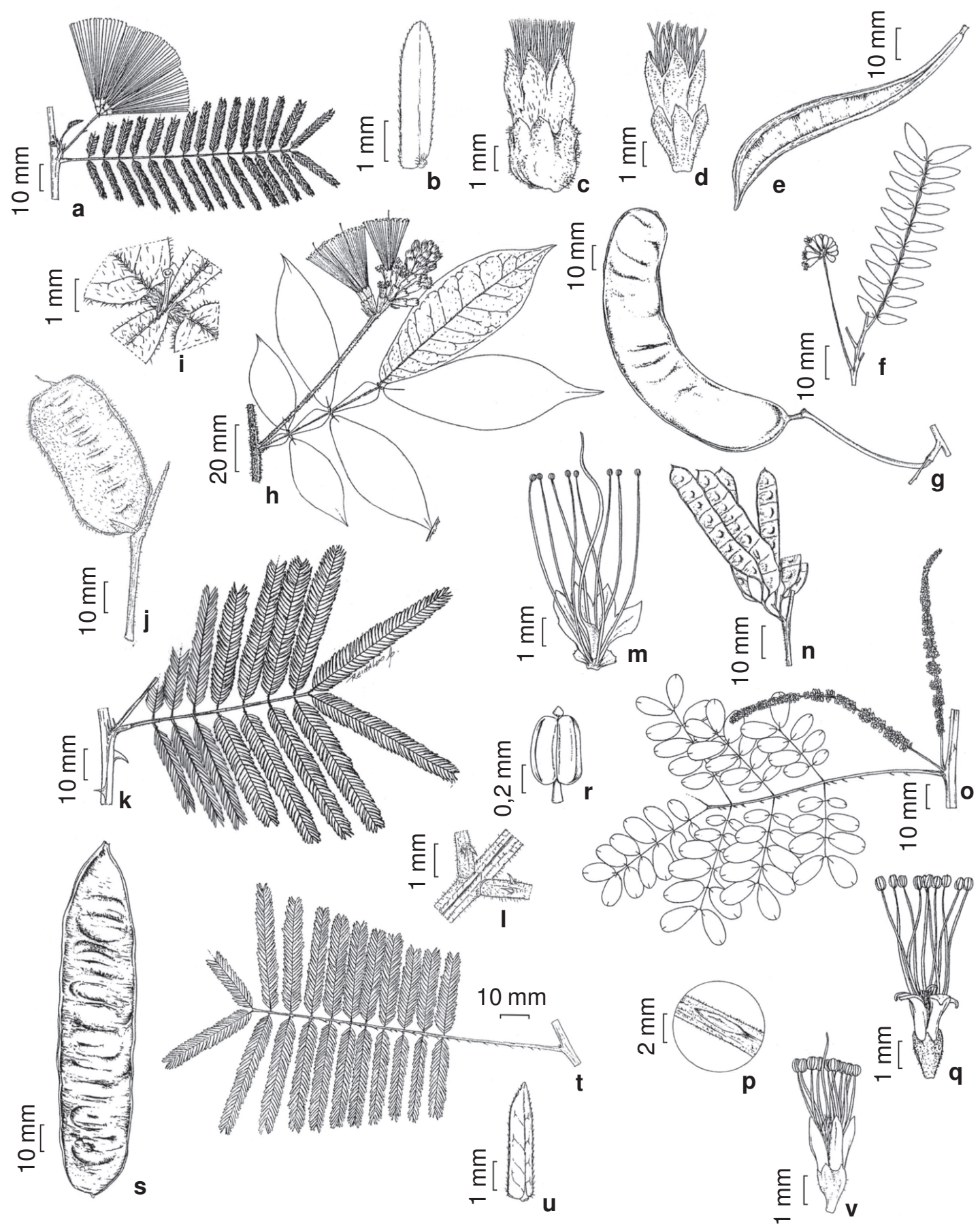

Figura 3 - a-e. Calliandra parvifolia - a. ramo com inflorescência; b. foliólulo; c. flor terminal; d. flor periférica (Lima 382); e. fruto (Lima 248). f-g. Inga schinifolia - f. ramo com inflorescência (Magalhães-Gomes s.n. OUPR 4568); g. fruto (Messias 272). h-j. I. vulpina - h. ramo com inflorescência; i. nectário (Lima 211); j. fruto (Lima 4066). k-n. Mimosa bimucronata var. bimucronata - k. folha; l. detalhe do par de acúleos na base do pecíolo; m. flor em corte longitudinal; n. frutos (Lima 325). o-s. Piptadenia adiantoides - o. ramo com inflorescência; p. nectário; q. flor; r. antera glandular (Lima 310); s. fruto (Lima 300). t-v. P. micracantha - t. folha; u. foliólulo (Lima 390); v. flor (Silva s.n. OUPR 1450). 
de Janeiro, Minas Gerais, Goiás e Paraná, ocupando margens de rio, campo cerrado, dunas, campinarana e floresta atlântica, habitando um gradiente altitudinal de 650-900 m (Barneby 1998; Queiroz 2004). No PEI, foi coletada em floresta estacional submontana.

9. Inga schinifolia Benth., London J.Bot. 4. 584. 1845.

Fig. $3 \mathrm{f}-\mathrm{g}$

Arbusto ou arvoreta $3 \mathrm{~m}$ alt., ramo cilíndrico, gabro. Estípula 3-4 mm compr., linear-lanceolada, caduca; pecíolo 0,3-1,3 cm compr., glabro ou glabrescente; raque 2,9$11,5 \mathrm{~cm}$ compr., marginada, glabra ou glabrescente; nectário estipitado, circular, entre todos os pares de folíolos. Folha (14-)16-28foliolada; folíolos 1,3-2,5×0,4-0,9 cm, opostos, rômbicos ou elípticos, base aguda, ápice agudo ou mucronulado, ambas as faces glabras. Inflorescência capituliforme, axilar, homomórfica; pedúnculo $34 \mathrm{~mm}$ compr., pubérulo; raque globosa, diâmetro da inflorescência $12-13 \mathrm{~mm}$ (excluindo os filetes). Flor pentâmera, actinomorfa, curto-pedicelada, pedicelo $0,1 \mathrm{~mm}$ compr.; cálice 1-1,2 mm compr., campanulado, pubérulo externamente; corola gamopétala, 5-5,2 mm compr., pubérula externamente; estames 22-24, filetes brancos, tubo estaminal exserto, $6 \mathrm{~mm}$ compr., filetes livres $6 \mathrm{~mm}$ compr., glabros, anteras eglandulares; ovário $1 \mathrm{~mm}$ compr., glabro, estípite $0,1 \mathrm{~mm}$ compr.; estilete $12 \mathrm{~mm}$ compr., glabro. Legume nucóide, $9 \times 9,5 \mathrm{~cm}$, levemente recurvado, plano compresso, margem reta, ápice apiculado, glabro; sementes $16,11 \times 5 \mathrm{~mm}$, oblongas, enegrecidas, com sarcotesta.

Material examinado: mata do Manso, 12.XII.1990, st., H. C. Lima etal. 4054 (OUPR); trilha do Baú, 15.VI.2005, st., L. C. P. Lima \& F. C. P. Garcia 391 (VIC).

Material adicional examinado: BRASIL. MINAS GERAIS: Ouro Preto, APA das Andorinhas, Serra da Brígida, 18.X.1999, fr., M. C. T. B. Messias 272 (OUPR); Morro São Sebastião, 27.II.1895, fl., C. H. Magalhães-Gomes s.n. (OUPR 4568).

O número (7-14) e o tamanho dos folíolos $(1,3-2,5 \times 0,4-0,9 \mathrm{~cm})$ são características que diferenciam Inga schinifolia das outras espécies do gênero ocorrentes nas florestas do PEI. Pennington (1997) considerou $I$. schinifolia como sinônimo de I. tenuis, enquanto Garcia (1998) as considerou como espécies distintas. Inga schinifolia diferenciase de I. tenuis, por apresentar pedúnculo da inflorescência reto e menor que $5,5 \mathrm{~cm}$ comprimento. No Brasil está distribuída nos estados de Minas Gerais, Rio de Janeiro e São Paulo, ocupando áreas de floresta estacional decidual montana e floresta ombrófila densa montana (Garcia 1998). No PEI, foi coletada em floresta estacional altimontana.

10. Inga vulpina Mart. ex Benth., Trans. Linn. Soc. London 30(3): 625. 1875. Fig. 3 h-j

Arbusto ou árvore 2-8 m alt., ramo cilíndrico, ferrugíneo-hirsuto. Estípula 3-4 mm compr., ovada, caduca; pecíolo 1-2,5 cm compr., ferrugíneo-hirsuto; raque 3,5-6,8 cm compr., alada, ferrugíneo-hirsuta; nectário estipitado, cupuliforme, entre todos os pares de folíolos. Folha 6-8-foliolada; folíolos 6,5-9,2×2-3,5 cm, opostos, elípticos ou lanceolados, base aguda, ápice agudo ou apiculado, face adaxial glabrescente, face abaxial hirsuta. Inflorescência espiciforme, axilar, homomórfica; pedúnculo 50-60 mm compr., tomentoso; raque $20 \mathrm{~mm}$ compr. Flor pentâmera, actinomorfa, séssil; cálice 6,5-7 mm compr., campanulado, hirsuto externamente; corola gamopétala, $12,2-13 \mathrm{~mm}$ compr., setosa externamente; estames 52-58, filetes róseos, tubo estaminal incluso, $8 \mathrm{~mm}$ compr., filetes livres 20-22 mm compr., glabros, anteras eglandulares; ovário $2 \mathrm{~mm}$ compr., glabro, estípite $0,5 \mathrm{~mm}$ compr.; estilete 25,5 mm compr., glabro. Legume nucóide, $5-5,5 \times 2,5-2,6 \mathrm{~cm}$, plano compresso, margem reta, ápice obtuso, ferrugíneo-tomentoso; sementes $8-11,7 \times 3 \mathrm{~mm}$, oblongas, castanhas, com sarcotesta.

Material examinado: estrada de Baixo, 12.XII.1990, fr., H. C. Lima et al. 4066 (OUPR); mata do Manso, próximo do alojamento, 19.IX.2004, fl., L. C. P. Lima \& F. C. P. Garcia 211 (VIC).

Inga vulpina é uma espécie próxima de I. barbata Benth., da qual se diferencia pelo tamanho da estípula 3-4 mm de compr., cálice hirsuto externamente e os filetes róseos; são 
espécies simpátricas no Rio de Janeiro, São Paulo e Minas Gerais (Garcia 1998; Dutra 2005). I. vulpina ocorre da Bahia até Santa Catarina, habitando matas de altitude, acima de $400 \mathrm{~m}$, sendo uma das poucas espécies de Inga que sobrevive em solos pedregosos dos campos rupestre e cerrado de Minas Gerais (Garcia 1998). No PEI, foi coletada em floresta estacional altimontana.

11. Mimosa bimucronata $O$. Kuntze var. bimucronata, Podr. 2: 469. $1825 . \quad$ Fig. 3 k-n Arbusto 3-7 m alt., ramo cilíndrico, pubescente, acúleos recurvos. Estípula 5-7 mm compr., lanceolada, persistente; pecíolo 1,1$1,5 \mathrm{~cm}$ compr., glabrescente, aculeado; raque 5-7,4 cm compr., canaliculada, glabrescente; nectário ausente. Folha bipinada, pinas (7-) 8-10 pares; foliólulos 22-30 pares, 8-9 $\times 1-$ $1,2 \mathrm{~cm}$, opostos, oblongos, base oblíqua, ápice agudo, face adaxial glabrescente ou pubescente, face adaxial glabra. Inflorescência capituliforme reunida em fascículo axilar ou panícula terminal, homomórfica; pedúnculo 9-10 mm compr., pubérulo; raque globosa, diâmetro da inflorescência 4-5 mm (excluindo filetes). Flor tetrâmera, actinomorfa, séssil; cálice $0,8 \mathrm{~mm}$ compr., campanulado, glabro externamente; corola gamopétala, $3 \mathrm{~mm}$ compr., glabra externamente; estames 8 , filetes brancos, livres, 4-8 mm compr., glabros, anteras eglandulares; ovário $0,8 \mathrm{~mm}$ compr., glabro, estípite $0,1 \mathrm{~mm}$ compr.; estilete $9 \mathrm{~mm}$ compr., glabro. Craspédio, 3,8-4,5 × 0,5-0,7 $\mathrm{cm}$, plano compresso, margem reta, ápice apiculado, glabro; sementes 5-7, $3 \times 1 \mathrm{~mm}$, ovadas, castanho-claras.

Material examinado: estrada em direção a trilha de Belém, 31.III.2005, fl. e fr., L. C. P. Lima et al. 325 (VIC).

O par de acúleos na base do pecíolo, o número de foliólulos, inflorescência amplamente paniculada são diagnósticos de Mimosa bimucronata (Barneby 1991). Segundo esse mesmo autor, a espécie possui duas variedades: a típica e $M$. bimucronata var.adenocarpa, sendo diferenciadas pelo menor número de pares de foliólulos (até 30) e o comprimento dos mesmos acima de $8 \mathrm{~cm}$ na variedade típica.
M. bimucronata var. bimucronata distribui-se de Pernambuco ao Rio Grande do Sul, ocupando áreas de floresta estacional semidecidual, mata atlântica e cerrado (Barneby 1991; Mendonça et al. 1998). No PEI, foi coletada em floresta estacional montana e submontana.

12. Piptadenia adiantoides (Spreng.) J.F. Macbr., Contrib. Gray. Herb. 59: 17. 1919.

Fig. 3 o-s

Liana armada, ramo cilíndrico, tomentoso, acúleos recurvos. Estípula $3 \mathrm{~mm}$ compr., lanceolada, caduca; pecíolo 4,3-10 cm compr., tomentoso, acúleos recurvos; raque 4,6-10,3 cm compr., cilíndrica, tomentosa, acúleos recurvos; nectário séssil, pateliforme, entre a maioria dos pares de pinas e pares de foliólulos. Folha bipinada, pinas (3-)4-6 pares; foliólulos 4-6 pares, $1,5-2,7 \times 0,9-1,5 \mathrm{~cm}$, opostos ou subopostos, obovados, base aguda, ápice obtuso ou mucronulado, ambas as faces glabras ou pubescentes. Inflorescência espiciforme, axilar, homomórfica; pedúnculo 8-18 mm compr., tomentoso; raque $60-98 \mathrm{~mm}$ compr. Flor pentâmera, actinomorfa, séssil; cálice 1,2 mm compr., campanulado, pubérulo externamente; corola dialipétala, $3 \mathrm{~mm}$ compr., glabra externamente; estames 10, filetes brancos ou avermelhados, livres, 6-7 $\mathrm{mm}$ compr., glabros, anteras glandulares na antese; ovário $1 \mathrm{~mm}$ compr., seríceo, estípite $1,2 \mathrm{~mm}$ compr.; estilete 0,5-3 mm compr., glabro. Legume, 9,5-12,5 × 2,1-2,6 cm, plano compresso, margem reta, ápice apiculado, glabrescente; sementes 9-12, $8 \times 4,2 \mathrm{~mm}$, obovadas, enegrecidas.

Material examinado: Cibrão, 23.III.2004, fl., M. C. T. B. Messias 868 (OUPR); 17.II.2005, fr., L. C. P. Lima et al. 300 (VIC); trilha da Alcan, 29.III.2005, fl., L. C. P. Lima \& E. D. Silva 310 (VIC).

Os ramos aculeados e os folíolos obovados maiores que $1,5 \mathrm{~cm}$ de comprimento, diferenciam Piptadenia adiantoides das demais Mimosoideae ocorrentes no PEI. No Brasil, ocorre no Pará, Paraíba, Bahia, Espírito Santo, Rio de Janeiro, São Paulo, Minas Gerais, Goiás e Distrito Federal (Bentham 1876; Lewis 1987; Tamashiro 1989; 
Mendonça-Filho 1996). No PEI, foi coletada em floresta estacional submontana e altimontana, e observada em áreas de floresta estacional altimontana.

13. Piptadenia micracantha Benth., Trans. Linn. Soc. London 30(3): 369. 1875.

Fig. $3 \mathrm{t}-\mathrm{v}$

Liana armada, ramo cilíndrico, tomentoso, acúleos recurvos. Estípula 3-5 mm compr., linear, caduca; pecíolo 2,3-3,4 cm compr., tomentoso, acúleos recurvos; raque $5,4-10 \mathrm{~cm}$ compr., estriada, tomentosa, acúleos recurvos; nectário séssil, pateliforme, nos pares de pinas distais e pares de foliólulos distais. Folha bipinada, pinas 8-15 pares; foliólulos 30-49 pares, 5-6,3 $\times 0,9-1,1 \mathrm{~cm}$, opostos, lineares ou linear-falcados, base oblíqua, ápice agudo, ambas as faces glabras, ciliado. Inflorescência espiciforme, terminal, homomórfica; pedúnculo $12 \mathrm{~mm}$ compr., tomentoso; raque $86 \mathrm{~mm}$ compr. Flor pentâmera, actinomorfa, séssil; cálice $1 \mathrm{~mm}$ compr., campanulado, glabrescente externamente; corola dialipétala, $3 \mathrm{~mm}$ compr., glabra externamente; estames 10 , filetes avermelhados, livres, 3-4 mm compr., glabros, anteras glandulares na antese; ovário $1 \mathrm{~mm}$ compr., seríceo, estípite $1 \mathrm{~mm}$ compr.; estilete 3 mm compr., glabro. Legume, 12-15,5 $\times 2,5-$ $2,7 \mathrm{~cm}$, plano compresso, margem sinuosa, ápice apiculado, glabrescente; sementes 8-10, 8-9 $\times 5-6 \mathrm{~mm}$, obovadas ou orbiculares, castanho-escuras.

Material examinado: estrada do Cibrão, 22.VIII.2005, fr., L. C. P. Lima \& J. C. Duelhi-Filho 390 (VIC); estrada para fazenda do Manso, 14.IV.1994, fl., J. $L$. Silva et al. s.n. (OUPR 1450); trilha do Baú, 25.IX.2005, fr., L. C. P. Lima et al. 380 (VIC).

Piptadenia micracrantha, quando estéril, pode ser diferenciada das espécies de Acacia ocorrentes no PEI, pelo nectário séssil, pateliforme. Distribui-se em Minas Gerais, Rio de Janeiro e São Paulo (Bentham 1876; Barroso 1965; Tamashiro 1989), sendo exclusiva da floresta atlântica (Lima et al. 1994). No PEI, foi coletada em floresta estacional submontana e altimontana.

\section{Papilionoideae}

14. Aeschynomene elegans Cham. \& Schltdl. var. elegans, Linnaea 5: 583-584. 1830.

Fig. 4 a.

Erva prostrada, ramo cilíndrico, seríceo. Estípula 5-7 $\mathrm{mm}$ compr., lanceolada, persistente; estipela ausente; pecíolo $0,3-1 \mathrm{~cm}$ compr., hirsuto; raque 1,5-2,5 cm compr., cilíndrica, hirsuta. Folha 8-12-foliolada, paripinada; folíolos $1,1-1,3 \times 0,4-0,6 \mathrm{~cm}$, alternos, oblongos ou obovados, base aguda, ápice mucronado, margem inteira, ambas as faces seríceas, venação broquidódroma, concolor. Inflorescência racemosa, axilar, 812-flora; pedúnculo 1,5 cm compr., seríceo; raque $1-1,2 \mathrm{~cm}$ compr., serícea. Flor zigomorfa, pedicelada, pedicelo $0,5-0,8 \mathrm{~cm}$ compr.; cálice 3 mm compr., campanulado, 5-laciniado, lacínios $0,5 \mathrm{~mm}$ compr., seríceo externamente; corola amarela, estandarte $7-8 \mathrm{~mm}$ compr., glabro externamente, alas 7-8 $\mathrm{mm}$ compr., pétalas da carena 7-8 mm compr.; androceu heterodínamo, estames 10, diadelfos (5+5), 5-7 mm compr., anteras isomorfas; ovário 2-3 $\mathrm{mm}$ compr., tomentoso, estípite $2 \mathrm{~mm}$ compr.; estilete $2 \mathrm{~mm}$ compr., curvado, glabro; estigma terminal, glabro. Lomento 4-6 articulado, 2,5-2,8 $\times 0,2-$ $0,3 \mathrm{~cm}$, artículo oboval depresso, ápice agudo, uncinado; sementes 4-6, 1,5 × $1 \mathrm{~mm}$, ovadareniformes, castanhas-claras.

Material examinado: estrada de baixo, 4.II.2002, fl.e fr., V. F. Dutra 97 (OUPR); trilha da Alcan, 24.X.2004, fl. e fr., L. C. P. Lima \& F. C. P. Garcia 225 (VIC).

Aeschynomene elegans é uma espécie próxima de A. falcata (Poir.) DC., da qual se diferencia pelo número de folíolos (10-12) e tricoma uncinado sobre a superfície do fruto (Fernandes 1996; Lima et al. 2006). A. elegans possui duas variedades: A. elegans $\mathrm{e}$ A. robustior Rudd, sendo a variedade típica diferenciada principalmente pelos folíolos com até $13 \mathrm{~mm}$ compr. (Fenandes 1996). Ocorre do México ao Uruguai e sul da Argentina (Brandão 1992). No Brasil distribui-se de Pernambuco até Rio Grande do Sul, habitando florestas e campos rupestres (Rudd 1955; Fernandes 1996). No PEI, foi coletada em floresta estacional altimontana. 


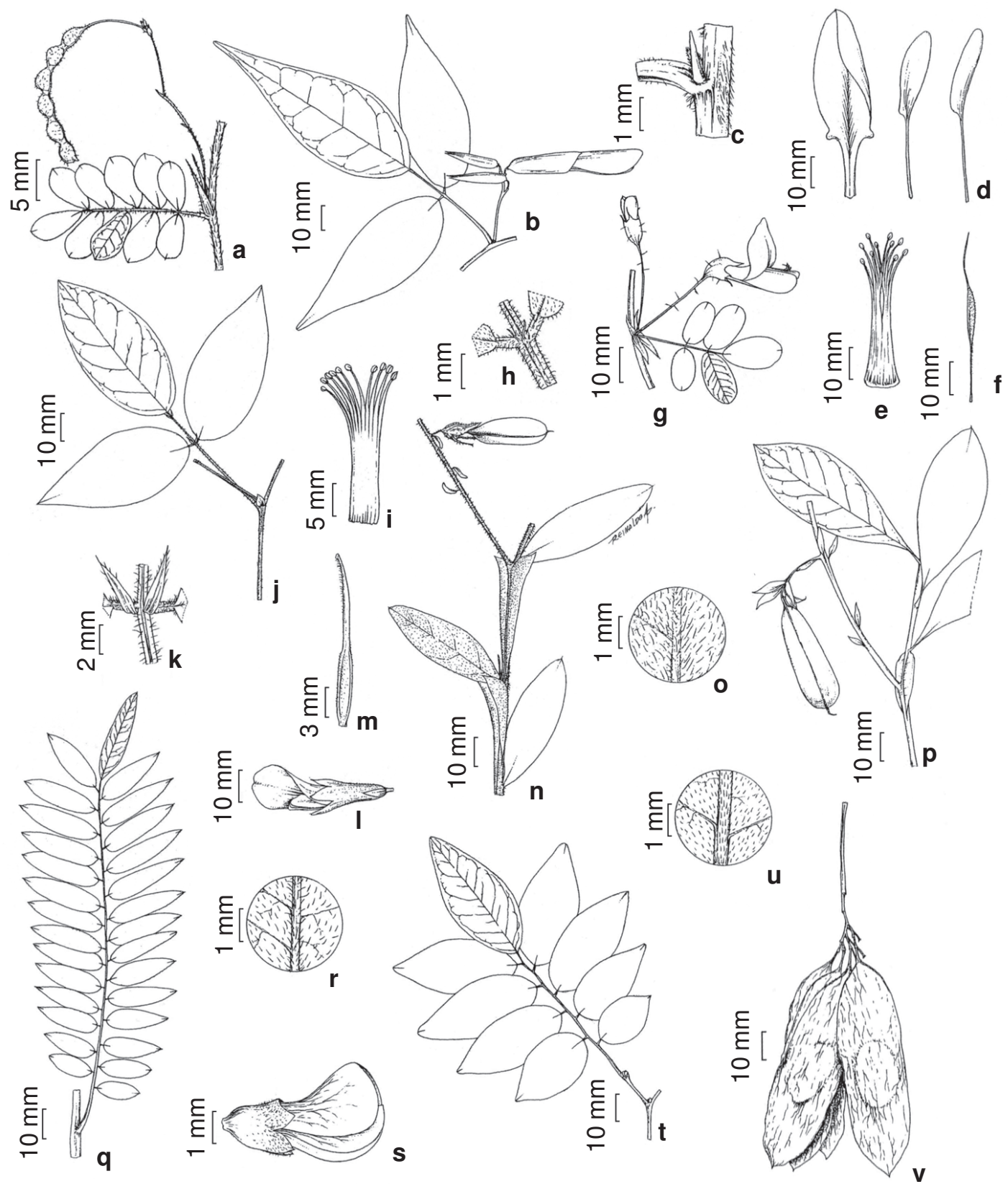

Figura 4 - a. Aeschynomene elegans var. elegans - a. ramo com fruto (Lima 225). b-f. Camptosema bellum - b. ramo com inflorescência; c. estípula; d. peças da corola; e. androceu; f. gineceu (Messias 884). g-i. Chaetocalyx longiflora - g. ramo com flores (Vidal 538); h. estipela (Lima 406); i. androceu (Vidal 538). j-m. Clitoria falcata var. falcata - j. folha; k. estipela; 1. flor; m. gineceu (Messias 859). n-o. Crotalaria breviflora - n. ramo com fruto; o. detalhe do indumento da face adaxial do folíolo (Lima 312). p. C. paulina - p. ramo com fruto (Lima 324). q-s. Dalbergia brasiliensis - q. folha; r. face abaxial do folíolo; s. flor (Lima 308). t-v. D. frutescens var. frutescens - t. folha; u. face abaxial do folíolo; v. frutos (Lima 330). 
15. Camptosema bellum (Mart.) Benth., Fl. bras. 15 (1B): 156. $1862 . \quad$ Fig. 4 b-f.

Trepadeira, ramo cilíndrico, seríceo ou hirsuto. Estípula $2 \mathrm{~mm}$ compr., lanceolada, caduca; estipela 1,5 mm compr., lanceolada, caduca; pecíolo 2-3,2 cm compr., seríceo; raque $0,8-$ $1,2 \mathrm{~cm}$ compr., estriada, serícea. Folha 3foliolada, imparipinada; folíolos laterais simétricos; folíolo terminal 2,5-12×0,9-3,8 cm, elíptico ou lanceolado, base aguda ou obtusa, ápice agudo, margem inteira, face adaxial glabra, face abaxial serícea, venação broquidódroma, concolor. Inflorescência pseudoracemosa, axilar, 2-5-flora; pedúnculo $1-1,2$ cm compr., glabro; raque $0,9-1,2 \mathrm{~cm}$ compr., glabra. Flor zigomorfa, não ressupinada, pedicelada, pedicelo $0,3-0,6 \mathrm{~cm}$ compr.; cálice 28-32 mm compr., tubuloso, 4-laciniado, lacínios 5-12 mm compr., seríceo externamente; corola vermelha, estandarte $48-58 \mathrm{~mm}$ compr., glabro externamente, alas $45-55 \mathrm{~mm}$ compr., pétalas da carena retas $45-55 \mathrm{~mm}$ compr.; androceu heterodínamo, estames 10 , diadelfos (5+5), 41-43 mm compr., anteras isomorfas; ovário 13-15 mm compr., tomentoso, estípite 12-20 mm compr.; estilete $18 \mathrm{~mm}$ compr., reto, glabro; estigma terminal, glabro. Fruto não observado; semente não observada.

Material examinado: Cibrão, 23.III.2004, fl., M. C. T. B. Messias 884 (OUPR); 30.III.2005, fl., L. C. P. Lima et al. 320 (VIC); trilha do Baú, 16.III.2004, fl., V. F. Dutra \& F. C. P. Garcia 182 (VIC); 29.III.2005, fl., L. C. P. Lima \& E. D. Silva 315 (VIC).

Camptosema bellum diferencia-se das demais espécies do gênero pelo número reduzido de flores na inflorescência (Queiroz 1999). Apesar de florescer em várias trilhas do PEI, a mesma não frutificou no período de estudo. Segundo esse mesmo autor, que revisou Camptosema para o Brasil, também não encontrou frutos $C$. bellum nos herbários consultados, com isto pode-se inferir que esta espécie deve ter alguma dificuldade reprodutiva. Ocorre nos estados de Minas Gerais e Espírito Santo, em áreas serranas associadas à Serra da Mantiqueira (Queiroz 1999). No PEI, distribui-se em floresta estacional altimontana, submontana e montana.
16. Chaetocalyx longiflora Benth. ex A. Gray, U.S. Expl. Exped., Phan. 1: 423. 1854.

Fig. 4 g-i.

Trepadeira, ramo estriado, tomentoso. Estípula 10-12 mm compr., lanceolada, persistente; estipela $0,5 \mathrm{~mm}$ compr., linear, caduca; pecíolo 2,8-3 cm compr., tomentoso; raque $1,5-2 \mathrm{~cm}$ compr., estriada, tomentosa. Folha 5-foliolada, imparipinada; folíolos 2-2,8 $\times 0,5-1 \mathrm{~cm}$, opostos, elípticos ou oblongos, base aguda ou obtusa, ápice agudo ou apiculado, margem inteira, ambas as faces pubescentes, venação broquidódroma, discolor. Inflorescência em fascículo, axilar, 2-4-flora. Flor zigomorfa, pedicelada, pedicelo 2,5-3 cm compr.; cálice $13 \mathrm{~mm}$ compr., campanulado, giboso, 5-laciniado, lacínios 3-5 mm compr., pubescente e glandular externamente; corola amarela, estandarte $30 \mathrm{~mm}$ compr., pubescente externamente, alas $25 \mathrm{~mm}$ compr., pétalas da carena $26 \mathrm{~mm}$ compr.; androceu heterodínamo, estames 10 , monadelfos, 22-25 mm compr., anteras uniformes; ovário $12 \mathrm{~mm}$ compr., barbado, estípite $3 \mathrm{~mm}$ compr.; estilete $11 \mathrm{~mm}$ compr., curvado, ciliado; estigma terminal, glabro. Fruto não observado; semente não observada.

Material examinado: Cibrão, 20.I.2005, st., L. C. P. Lima et al. 406 (VIC).

Material adicional examinado: BRASIL. MINAS GERAIS: Viçosa, Universidade Federal de Viçosa, Tanque da Pisicultura, 6.VII.1979, fl., W. N. Vidal \& M. R. R. Vidal 538 (VIC).

Chaetocalyx longiflora é facilmente reconhecida entre as Papilionoideae do PEI, pelo hábito trepador e número de folíolos (5). Segundo Rudd (1958), C. longiflora é semelhante a $C$. scandens (L.) Urb., pela largura dos folíolos $(0,5-2,5 \mathrm{~cm})$, sendo diferenciada pelo cálice giboso e estandarte maior que $22 \mathrm{~mm}$ de comprimento. Existem registros desta espécie para a Bolívia e o Brasil, onde ocorre desde a Bahia até o Paraná (Rudd 1958; Lewis 1987). No PEI, foi coletada em floresta estacional submontana. 
17. Clitoria falcata Lam. var. falcata, Encycl. 2(1): 51. $1786 . \quad$ Fig. 4 j-m

Trepadeira, ramo estriado, hirsuto. Estípula 4-5 mm compr., ovado-lanceolada, persistente; estipela 4-5 mm compr., ovadolanceolada, persistente; pecíolo $2,5-3 \mathrm{~cm}$ compr., hirsuto; raque $0,8-1,7 \mathrm{~cm}$ compr., estriada, hirsuta. Folha 3-foliolada, imparipinada; folíolos laterais assimétricos; folíolo terminal 4,5-7 × 2,4-3,5 cm, ovado ou elíptico, base obtusa, ápice agudo, margem inteira, face adaxial glabra, face abaxial serícea, venação broquidódroma, discolor. Inflorescência racemosa, axilar, 4-flora; pedúnculo 4-6 cm compr., hirsuto; raque $0,6-0,8 \mathrm{~cm}$ compr., hirsuta. Flor zigomorfa, ressupinada, pedicelada, pedicelo $0,2 \mathrm{~cm}$ compr.; cálice $20 \mathrm{~mm}$ compr., tubuloso, 5-laciniado, lacínios 8-12 mm compr., hirsuto externamente; corola branca, estandarte $28 \mathrm{~mm}$ compr., glabro externamente, alas $25 \mathrm{~mm}$ compr., pétalas da carena retas $24 \mathrm{~mm}$ compr.; androceu heterodínamo, estames 10 , diadelfos $(5+5)$, 15-20 mm compr., anteras uniformes; ovário $8 \mathrm{~mm}$ compr., puberulento, estípite $1 \mathrm{~mm}$ compr.; estilete $10 \mathrm{~mm}$ compr., reto, ciliado; estigma terminal, glabro. Fruto não observado; semente não observada.

Material examinado: Cibrão, 24.III.2004, fl., M. C. T. B. Messias 859 (OUPR); estrada entre Serrinha e Cibrão, 29.III.2004, fl., V. F. Dutra et al. 312 (VIC).

Clitoria falcata possui três variedades: C. falcata var. falcata, C. falcata var. longifolia e C. falcata var. latifolia. A variedade típica é facilmente reconhecida pelas flores brancas, podendo também ser diferenciada da var. longifolia pelos folíolos menores que $7 \mathrm{~cm}$ comprimento, e da var. latifolia, pelos folíolos elípticos (Miotto 1987a). Ocorre na América do Sul tropical, América Central e África tropical (Ildis 2005). No Brasil, distribui-se nos estados do Amazonas, Pará, Goiás, e da Bahia até o Rio Grande do Sul, habitando áreas abertas, campos arbustivos, secos ou inundados e matas com solo arenoso (Fantz 1980; Miotto 1987a). No PEI, foi coletada em área de floresta estacional submontana.
18. Crotalaria breviflora DC., Prodr. 2: 127. 1825.

Fig. 4 n-o

Erva ereta ou subarbusto $0,5-1,5 \mathrm{~m}$ alt., ramo cilíndrico, velutino ou viloso, caule alado. Estípula não observada, caduca; estipela ausente; ala internodal $3-4 \mathrm{~cm}$ compr. Folha 1-foliolada; folíolo 3,5-7,5 $\times$ 0,8-2,4 cm, elíptico ou oblongo, base aguda, ápice agudo ou apiculado, margem inteira, ambas as faces seríceas, venação camptódroma, discolor. Inflorescência racemosa, terminal, 6-12-flora; pedúnculo 1,5-4 cm compr., hirsuto ou viloso; raque 3-10 cm compr., hirsuta ou vilosa. Flor zigomorfa, pedicelada, pedicelo $0,3-0,5 \mathrm{~cm}$ compr.; cálice 12-14 mm compr., campanulado, 5-laciniado, lacínios 6-10 mm compr., seríceo externamente; corola amarela, estandarte 14-16 mm compr., glabro externamente, alas 13-14 mm compr., pétalas da carena 13-14 mm compr.; androceu heterodínamo, estames 10 , monadelfos, 11-12 mm compr., anteras heteromorfas; ovário 7,2 mm compr., glabro, estípite $1 \mathrm{~mm}$ compr.; estilete $8 \mathrm{~mm}$ compr., curvado, glabro; estigma terminal, ciliado. Legume, 3-3,5 × 0,7-0,8 cm, inflado, oblanceolado, ápice apiculado, glabro; sementes $24-28,3 \times 2 \mathrm{~mm}$, reniformes, castanha-escuras.

Material examinado: estrada da Torre, 29.III.2005, fr., L. C. P. Lima \& E. D. Silva 312 (VIC); trilha da Alcan, 25.IV.2005, fl., L. C. P.Lima \& E. D. Silva 334 (VIC); trilha do Baú, 27.II.2002, fl., M. C. T. B. Messias 645 (OUPR); 19.I.2005, fl., L. C. P. Lima \& F. C. P. Garcia 263 (VIC).

O indumento velutino ou viloso dos ramos e os folíolos elípticos ou oblongos são características que diferenciam Crotalaria breviflora de C. paulina. No Brasil ocorre nos estados da Bahia, Rio de Janeiro, São Paulo, Minas Gerais, Distrito Federal, Goiás, Mato Grosso e Paraná (Filiettaz 2002). Habita áreas de cerrado, campo rupestre, campo de altitude e mata atlântica, em borda de mata, local úmido e brejoso (Filiettaz 2002). No PEI, ocorre em áreas de floresta estacional altimontana. 
19. Crotalaria paulina Schrank, Pl. Rar. Hort. Monac. pl. 88. 1822. Fig. $4 \mathrm{p}$

Subarbusto, ramo cilíndrico, glabro, glauco, caule alado. Estípula não observada, caduca; estipela ausente; ala internodal 2,6$45 \mathrm{~cm}$ compr. Folha 1-foliolada; folíolo 6-11× 2-3,7 cm, obovado, base aguda, ápice mucronulado, margem inteira, face adaxial glabra com tricomas seríceos na nervura principal, face abaxial serícea, venação broquidódroma, discolor. Inflorescência racemosa, terminal, 12-16-flora; pedúnculo 2,5-4 cm compr., glabro; raque $12-14 \mathrm{~cm}$ compr., glabra. Flor zigomorfa, pedicelada, pedicelo 1-1,2 cm compr.; cálice $16 \mathrm{~mm}$ compr., campanulado, 5-laciniado, lacínios 7$10 \mathrm{~mm}$ compr., glabro externamente; corola amarela, estandarte $20 \mathrm{~mm}$ compr., glabro externamente, alas $18 \mathrm{~mm}$ compr., pétalas da carena $18 \mathrm{~mm}$ compr.; androceu heterodínamo, estames 10, monadelfos, 13-14 mm compr., anteras heteromorfas; ovário $9 \mathrm{~mm}$ compr., glabro, estípite $1 \mathrm{~mm}$ compr.; estilete $12 \mathrm{~mm}$ compr., curvado, glabro; estigma terminal, ciliado. Legume, 5-6 × 1-1,2 cm, inflado, oblanceolado, ápice apiculado, glabro ou glabrescente; sementes $40,4 \times 3 \mathrm{~mm}$, reniformes, castanhas.

Material examinado: estrada do Cibrão, 17.II.2005, fl., L. C. P. Lima et al. 302 (VIC); 30.III.2005, fr., L. C. P. Lima et al. 324 (VIC).

Crotalaria paulina pode ser reconhecida por apresentar ramos totalmente glabros e glaucos (Filiettaz 2002). Distribuise pela Colômbia, Venezuela e Brasil, nos estados do Amazonas, Mato Grosso, Distrito Federal, Minas Gerais, Rio de Janeiro e São Paulo, ocupando campo rupestre, cerrado, sub-bosque ou margem de mata ciliar, floresta estacional montana, freqüentemente associada a locais úmidos ou brejosos, ou locais secos e solos arenosos (Polhil 1982; Filiettaz 2002). No PEI, foi coletada em floresta estacional submontana, em altitude de $676 \mathrm{~m}$, ampliando a faixa altitudinal desta espécie, que segundo Polhil (1982), ocupa altitudes entre 800-1300 m.
20. Dalbergia brasiliensis Vogel, Linnaea 11: 198. 1837.

Fig. 4 q-s

Liana, ramo cilíndrico, glabro ou puberulento, inerme. Estípula $10 \mathrm{~mm}$ compr., oblonga, caduca; estipela ausente; pecíolo 1,3-3,3 cm compr., tomentoso; raque 8,2$12,8 \mathrm{~cm}$ compr., cilíndrica, tomentosa. Folha 17-29-foliolada, imparipinada; folíolos 2,94,3 × 0,6-1,9 cm, alternos, lanceolados ou oblongos, base obtusa, ápice agudo, margem inteira, face adaxial glabra, face abaxial serícea, venação camptódroma, concolor. Inflorescência cimeira escorpióide, terminal, 12-15-flora por cimeira; pedúnculo 0,5-0,6 cm compr., tomentoso; raque $1-$ $1,2 \mathrm{~cm}$ compr., tomentosa. Flor zigomorfa, pedicelada, pedicelo $0,1 \mathrm{~cm}$ compr.; cálice $3 \mathrm{~mm}$ compr., campanulado, 5-laciniado, lacínios 1-1,5 mm compr., pubescente externamente; corola creme-esverdeada, estandarte $5 \mathrm{~mm}$ compr., glabro externamente, alas $5 \mathrm{~mm}$ compr., pétalas da carena $4 \mathrm{~mm}$ compr.; androceu heterodínamo, estames 911, monadelfos, 4-5 mm compr., anteras isomorfas; ovário $2 \mathrm{~mm}$ compr., ciliado, estípite $2 \mathrm{~mm}$ compr.; estilete $1 \mathrm{~mm}$ compr., reto, glabro; estigma terminal, glabro. Sâmara, $7-7,5 \times 2 \mathrm{~cm}$, elíptico-oblonga, região seminífera central, ápice agudo, glabro; semente $1,7 \times 4 \mathrm{~mm}$, oblonga-reniforme, castanha.

Material examinado: trilha de Belém, 21.I.2005, fr., L. C. P. Lima et al. 278 (VIC); 18.II.2005, fl., L. C. P. Lima et al. 308 (VIC).

No PEI, Dalbergia brasiliensis pode ser confundida com Dalbergia frutescens var. frustescens, da qual se diferencia pela folha 7-17-foliolada e folíolos lanceolados ou oblongos. Distribui-se pelos estados de Minas Gerais, Rio de Janeiro, São Paulo, em floresta montana, Paraná e Santa Catarina, onde ocorre em floresta de araucária (Carvalho 1997). No PEI, foi coletada em floresta estacional montana e observada em floresta estacional submontana. 
21. Dalbergia frutescens (Vell.) Britton var. frutescens, Bull. Torrey Bot. Club 16(12): 324. 1889.

Fig. $4 \mathrm{t}-\mathrm{v}$

Liana, ramo cilíndrico, glabro, inerme. Estípula não observada, caduca; estipela ausente; pecíolo 1,8-2,3 cm compr., puberulento ou tomentoso; raque 2,6-10,2 cm compr., cilíndrica, puberulenta ou tomentosa. Folha 7-11(-17)-foliolada, imparipinada; folíolos $3,5-5,6 \times 2-2,6 \mathrm{~cm}$, alternos, ovados ou elípticos, base obtusa ou aguda, ápice agudo, margem inteira, face adaxial glabra, face abaxial puberulenta, venação broquidódroma, concolor. Inflorescência cimeira escorpióide, terminal, 12-15-flora por cimeira; pedúnculo $1 \mathrm{~cm}$ compr., puberulento; raque $0,5-0,6 \mathrm{~cm}$ compr., puberulenta. Flor zigomorfa, pedicelada, pedicelo $0,1 \mathrm{~cm}$ compr.; cálice $3 \mathrm{~mm}$ compr., campanulado, 5-laciniado, lacínios 0,5-1 mm compr., pubescente externamente; corola creme-esverdeada, estandarte $4 \mathrm{~mm}$ compr., glabro externamente, alas $4 \mathrm{~mm}$ compr., pétalas da carena $4 \mathrm{~mm}$ compr.; androceu heterodínamo, estames 10, monadelfos, 2-3 mm compr., anteras isomorfas; ovário $2 \mathrm{~mm}$ compr., ciliado, estípite $1 \mathrm{~mm}$ compr.; estilete $1 \mathrm{~mm}$ compr., reto, glabro; estigma terminal, glabro. Sâmara, $6,5-7 \times 1,8-2 \mathrm{~cm}$, elípticooblonga, região seminífera central, ápice mucronulado, glabro; semente $1,10 \times 7 \mathrm{~mm}$, reniforme, castanha.

Material examinado: Calais, 20.I.2004, fl., V. F. Dutra et al. 162 (VIC); estrada de Baixo, 24.X.2004, fr., $L$. C. P. Lima \& F. C. P. Garcia 219 (VIC); trilha da Alcan, 31.III.2005, fr., L. C. P. Lima et al. 330 (VIC).

Dalbergia frutescens é uma espécie muito polimórfica, normalmente, apresenta-se como liana, sendo menos freqüente o hábito arbóreo e arbustivo escandente (Almeida 1953; Carvalho 1997). A delimitação taxonômica das variedades desta espécie, $D$. frutescens var. frutescens e $D$. frutescens var. tomentosa é tênue, baseada apenas no tipo de indumento (Carvalho 1997). Segundo esse memso autor, ocorre na Guiana, Venezuela, Argentina, Paraguai e Brasil, nas Regiões Nordeste, Centro-Oeste, Sudeste e Sul, habitando restinga, floresta atlântica ombrófila, floresta de galeria, e floresta de araucária, ocupando amplo gradiente altitudinal, desde nível do mar até $1200 \mathrm{~m}$. No PEI, foi coletada em floresta estacional altimontana.

22. Desmodium adscendens (Sw.) DC., Prodr. 2: 332. 1825.

Fig. 5 a-c

Erva prostrada, ramo cilíndrico, tomentoso ou viloso. Estípula 3-5 mm compr., lanceolada, persistente; estipela 1-2 mm compr., linear, caduca; pecíolo (0,6-)0,9-1,2 cm compr., seríceo ou tomentoso; raque $(0,3-) 0,4-0,6 \mathrm{~cm}$ compr., estriada, serícea ou tomentosa. Folha 3-foliolada, imparipinada; folíolos laterais simétricos; folíolo terminal (1,4-) 1,6-2,4 × $1,1-1,4 \mathrm{~cm}$, obovado ou orbicular, base aguda, ápice obtuso, margem inteira, ambas as faces pubescentes, venação broquidódroma, concolor. Inflorescência pseudo-racemosa, terminal, 20-flora; pedúnculo $2 \mathrm{~cm}$ compr., uncinado ou seríceo; raque $16 \mathrm{~cm}$ compr., uncinado ou seríceo. Flor zigomorfa, pedicelada, pedicelo $0,9-1 \mathrm{~cm}$ compr.; cálice $4 \mathrm{~mm}$ compr., campanulado, 5-laciniado, lacínios 2-3 mm compr., seríceo externamente; corola rósea, estandarte $6 \mathrm{~mm}$ compr., glabro externamente, alas $6 \mathrm{~mm}$ compr., pétalas da carena $6 \mathrm{~mm}$ compr.; androceu heterodínamo, estames 10 , diadelfos $(9+1), 4,5-5 \mathrm{~mm}$ compr., anteras uniformes; ovário 3-4 mm compr., seríceo, séssil; estilete $3 \mathrm{~mm}$ compr., curvado, tomentoso; estigma terminal, ciliado. Lomento 1-2 articulado, $0,8-1,4 \times 0,3-0,4 \mathrm{~cm}$, artículo oboval, compresso, ápice agudo, uncinado; sementes $1-2,4 \times 3 \mathrm{~mm}$, reniformes, castanhas.

Material examinado: Calais, 26.V.2004, fl., fr., V. F. Dutra \& S. C. Ferreira 237 (VIC); trilha da Alcan, 20.I.2005, st., L. C. P. Lima et al. 397 (VIC).

No PEI, o folíolo obovado ou orbicular distingue Desmodium adscendens de D. uncinatum. A forma do folíolo de Desmodium adscendens é uma característica de fácil reconhecimento entre as espécies do gênero ocorrentes no Brasil, entretanto, pode ser confundida com D. trifolium (L.) DC., da qual 
se diferencia pelo hábito prostrado e inflorescência pseudo-racemosa (Azevedo 1981). No Brasil pode ser encontrada nos estados do Amazonas, Acre, Pará, Mato Grosso, e da Bahia ao Rio Grande do Sul (Lewis 1987; Mendonça-Filho 1996). Habita formações de campo rupestre, restinga, cerrado, caatinga, ocorrendo em áreas de mata, capoeira e brejo (Azevedo 1981), sendo considerada espécie invasora bastante freqüente na planície litorânea (Lorenzi 1982). No PEI, foi coletada em floresta estacional submontana, e observada em floresta estacional altimontana e montana.

\section{Desmodium uncinatum (Jacq.) DC.,} Prodr. 2: 331. 1825.

Fig. 5 d-g

Subarbusto, ramo estriado, com tricoma uncinado. Estípula $3 \mathrm{~mm}$ compr., lanceolada, caduca; estipela 5-7 mm compr., linear, persistente; pecíolo $3-5 \mathrm{~cm}$ compr., hirsuto; raque $0,8-1,5 \mathrm{~cm}$ compr., estriada, hirsuta. Folha 3-foliolada, imparipinada; folíolos laterais simétricos; folíolo terminal 4,2-6×1,8-2,8 cm, ovado-lanceolado, base obtusa, ápice agudo ou apiculado, margem inteira, face adaxial pubescente-setosa, face abaxial velutina, venação camptódroma, geralmente com uma mácula acompanhando a nervura central, concolor. Inflorescência paniculada, terminal, 7-12-flora por racemo; pedúnculo $3,5 \mathrm{~cm}$ compr., uncinado ou hirsuto; raque $1,5 \mathrm{~cm}$ compr., uncinada ou hirsuta. Flor zigomorfa, pedicelada, pedicelo 1,1-1,2 cm compr.; cálice $4 \mathrm{~mm}$ compr., campanulado, 5-laciniado, lacínios 0,2-3 mm compr., hirsuto externamente; corola esverdeada, lilás ou azul, estandarte $11 \mathrm{~mm}$ compr., glabro externamente, alas $8 \mathrm{~mm}$ compr., pétalas da carena $8 \mathrm{~mm}$ compr.; androceu heterodínamo, estames 10, diadelfos (9+1), 7-8 mm compr., anteras uniformes; ovário $5 \mathrm{~mm}$ compr., seríceo, estípite $0,5 \mathrm{~mm}$ compr.; estilete $3 \mathrm{~mm}$ compr., curvado, glabro; estigma terminal, puberulento. Lomento 3-8 articulado, 2,5-4× $0,3-0,4 \mathrm{~cm}$, artículo trigonal ou rômbico, ápice agudo, uncinado-hirsuto; sementes 3-8, 2, 4× $2 \mathrm{~mm}$, arredondadas, castanha-esverdeadas.
Material examinado: estrada de Baixo, 28.IV.2005, fl. e fr., L. C. P. Lima \& E. D. Silva 348 (VIC); trilha do Baú, 29.III.2005, fl. e fr., L. C. P. Lima \& E. D. Silva 314 (VIC).

Desmodium unicatum diferencia-se das outras Papilionoideae ocorrentes no PEI, pelo ramo uncinado. É uma espécie próxima de $D$. subsericeum Malme, da qual se diferencia pelo ramo estriado, face abaxial do folíolo velutina e lomento uncinado-hirsuto (Azevedo 1981). No Brasil está distribuída no Mato Grosso do Sul, e da Bahia ao Rio Grande do Sul (Lewis 1987; Nobre -no prelo). Habita formações de cerrado, restinga, campo rupestre e áreas de matas, capoeiras, pastagens e locais úmidos, sendo referida como espécie invasora (Azevedo 1981). No PEI, ocorre em floresta estacional altimontana, e montana.

24. Dioclea violacea Mart. ex Benth., Comm. Legum. Gen. 69. 1837. Fig. $5 \mathrm{~h}$

Liana, ramo cilíndrico, ferrugíneopubescente, adpresso. Estípula não observada, caduca; estipela não observada, caduca; pecíolo 7,5-8 cm compr., ferrugíneo-pubescente; raque 0,5-1 cm compr., estriada, ferrugínea-pubescente. Folha 3-foliolada, imparipinada; folíolos laterais assimétricos; folíolo terminal 12,5-16,5 × 7,8$8,5 \mathrm{~cm}$, obovado, base obtusa, ápice obtuso, margem inteira, face adaxial pubescente, face abaxial hirsuta, venação broquidódroma, discolor. Inflorescência pseudo-racemosa, com nodosidades, axilar, 25-62-flora; pedúnculo 20-32 cm compr., seríceo; raque $16-16,5 \mathrm{~cm}$ compr., serícea. Flor zigomorfa, pedicelada, pedicelo $0,3 \mathrm{~cm}$ compr.; cálice $7 \mathrm{~mm}$ compr., tubuloso, 5-laciniado, lacínios 1-2 mm compr., seríceo externamente; corola rosa, estandarte $10 \mathrm{~mm}$ compr., pubescente externamente, alas $10 \mathrm{~mm}$ compr., pétalas da carena $10 \mathrm{~mm}$ compr.; androceu heterodínamo, estames 10 , diadelfos $(9+1), 7-8 \mathrm{~mm}$ compr., anteras uniformes; ovário $8 \mathrm{~mm}$ compr., ferrugíneoseríceo, estípite $2 \mathrm{~mm}$ compr.; estilete $3 \mathrm{~mm}$ compr., curvado, glabro; estigma terminal, glabro. Legume, $15 \times 5 \mathrm{~cm}$, oblongo, ápice obtuso, ferrugíneo-viloso; sementes 3, $3 \times 2,5$ $\mathrm{cm}$, reniformes, castanho-escuras. 

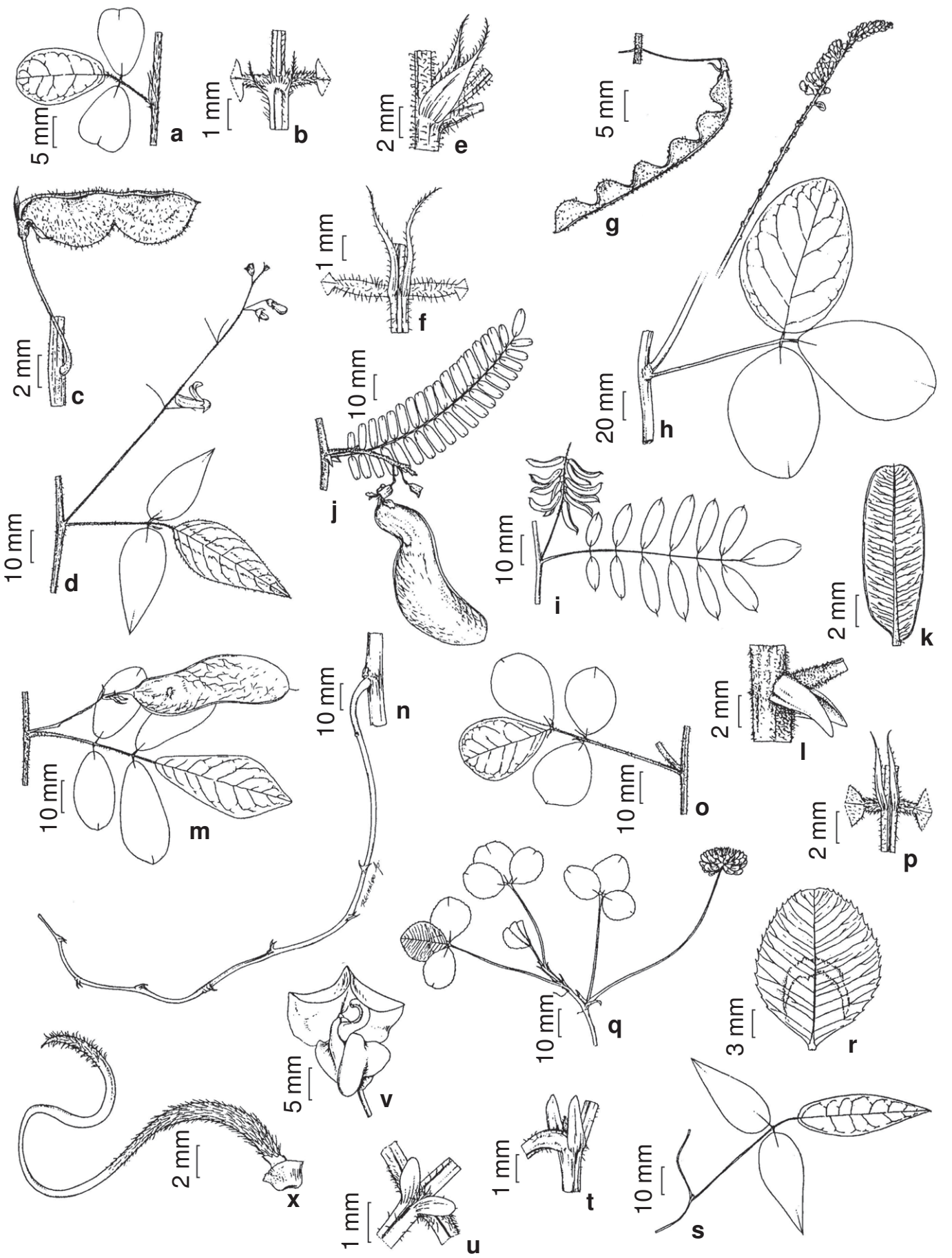

Figura 5 - a-c. Desmodium adscendens - a. folha; b. estipela; c. fruto (Dutra 237). d-g. D. uncinatum - d. ramo com inflorescência; e. estípula; f. estipela; g. fruto (Lima 314). h. Dioclea violacea - h. ramo com inflorescência (Lima 366). i. Indigofera suffruticosa - i. ramo com frutos (Lima 343). j-1. Machaerium aculeatum - j. ramo com fruto; k. estípula; 1. folíolo (Lima 369). m-n. M. oblongifolium - m. ramo com fruto; n. gavinha (Lima 299). o-p. Poiretia punctata - o. folha; p. estipela (Lima 295). q-r. Trifolium repens - q. ramo com inflorescência; r. folíolo (Lima 4060). s-x. Vigna peduncularis var. peduncularis - s. folha; t. estípula; u. estipela (Lima 337); v. flor; x. gineceu (Lima 351). 
Material examinado: estrada do Cibrão, 16.VI.2005, fl., L. C. P. Lima et al. 366 (VIC).

Material adicional examinado: BRASIL. MINAS GERAIS: Marliéria, Parque Estadual do Rio Doce, 20.V.1999, fr., R. L. C. Bortoluzzi et al. 658 (VIC).

Dioclea violacea caracteriza-se, entre as lianas estudadas, pelas folhas trifolioladas e corola rosa. Distribui-se na Argentina, Paraguai e Brasil, onde pode ser encontrada nas Regiões Norte, Sudeste e Sul (Burkart 1970; Miotto 1987b; Mendonça-Filho 1996). No PEI, foi coletada em floresta estacional submontana.

\section{Indigofera suffruticosa Mill., Gard. Dict} 8 n. 2.1768.

Fig. 5 i

Arbusto 1,5 m alt., ramo estriado, seríceo. Estípula linear, 4-5 mm compr., persistente; estipela linear, 1-2 $\mathrm{mm}$, persistente; pecíolo 1,62,3 cm compr., seríceo; raque 4-8 cm compr., cilíndrica, serícea. Folha 11-15-foliolada, imparipinada; folíolos 2,2-2,8 ×0,7-0,8 cm, opostos, elípticos ou obovados, base aguda, ápice obtuso ou agudo, margem inteira, face adaxial glabra, face abaxial serícea, venação não observada, concolor. Inflorescência racemosa, axilar, 10-34-flora; pedúnculo 0,4-0,5 cm compr., seríceo; raque 2-2,6 cm compr., serícea. Flor zigomorfa, pedicelada, pedicelo $0,1 \mathrm{~cm}$ compr.; cálice $1 \mathrm{~mm}$ compr., campanulado, 5-laciniado, lacínios 0,2 mm compr.; corola coral, estandarte 4,2 mm compr., seríceo externamente, alas 4,2 mm compr., pétalas da carena 4,2 mm compr.; androceu heterodínamo, estames 10, diadelfos (9+1), 3,2-4 mm compr., anteras unifomes; ovário $2 \mathrm{~mm}$ compr., seríceo, estípite $0,5 \mathrm{~mm}$ compr.; estilete $1,5 \mathrm{~mm}$ compr., curvado, glabro; estigma terminal, ciliado. Legume, 1,1-1,2 $\times 0,2 \mathrm{~cm}$, linear, ápice apiculado, seríceo; sementes 5-7, 1,2×1,2 mm, quadradas, castanhas.

Material examinado: Cibrão, 27.IV.2005, fl. e fr., $L$. C. P. Lima et al. 343 (VIC).

Indigofera suffruticosa é uma espécie próxima de I. truxillensis Kunth, da qual difere pelos folíolos glabros na face adaxial. Distribuise pelas Américas tropical e subtropical, habitando beiras de estradas, campos arbustivos e locais alterados (Eisinger 1987).
No PEI, foi coletada em sub-bosque alterado de floresta estacional submontana.

26. Machaerium aculeatum Raddi, Mem. Mat. Fis. Soc. Ital. Sci. Modena, Pt. Mem. Fis. 18(2): 398-399. 1820 . Fig. 5 j-1

Liana, armada, ramo cilíndrico, glabro ou tomentoso, sem gavinhas. Estípula $4 \mathrm{~mm}$ compr., espinescente, unciforme, persistente; estipela ausente; pecíolo 0,4-1,3 cm compr., tomentoso; raque 5,7-7 cm compr., cilíndrica, tomentosa. Folha 31-39-foliolada, imparipinada; folíolos 1,2-1,8 ×0,4-1 cm, alternos ou subopostos, oblongos, base oblíqua, ápice mucronulado, margem inteira, face adaxial glabrescente, face abaxial pubérula, venação craspedódroma, concolor. Inflorescência panícula, terminal, 5-12-flora por racemo; pedúnculo $0,6 \mathrm{~cm}$ compr., tomentoso; raque 0,9-1 cm compr., tomentosa. Flor zigomorfa, pedicelada, pedicelo $0,1 \mathrm{~cm}$ compr.; cálice 5 mm compr., campanulado, 5-laciniado, lacínios $1 \mathrm{~mm}$ compr., pubescente externamente; corola lilás, estandarte $6 \mathrm{~mm}$ compr., seríceo externamente, alas $6 \mathrm{~mm}$ compr., pétalas da carena $5 \mathrm{~mm}$ compr.; androceu heterodínamo, estames 10, monadelfos, 3-4 mm compr., anteras isomorfas; ovário $3 \mathrm{~mm}$ compr., seríceo, estípite $1 \mathrm{~mm}$ compr.; estilete $1 \mathrm{~mm}$ compr., reto, glabro; estigma terminal, glabro. Sâmara, 5,5-6 cm compr., falcada, região seminífera basal, ápice obtuso, tomentosa; semente $1,1,1 \times 0,5 \mathrm{~mm}$, oblongareniforme, enegrecida.

Material examinado: Cibrão, 20.XII.1993, fl., S. J. L. Dias s.n. (OUPR 8259); trilha de Belém, 17.VI.2005, fr., L. C. P. Lima et al. 369 (VIC).

O hábito lianescente, as estípulas espinescentes e unciformes são diagnósticos de Machaerium aculeatum, e também ajudam na diferenciação de M. hirtum (Vell.) Stellfeld, uma espécie muito próxima (Mendonça-Filho 1996; Bortoluzzi et al. 2004). Distribui-se na Argentina, Bolívia e Brasil, onde é citada para os estados de Pernambuco, Bahia, Minas Gerais, Rio de Janeiro e São Paulo (Lewis 1987; Mendonça-Filho 1996). No PEI, foi coletada em floresta estacional submontana e montana. 
27. Machaerium oblongifolium Vogel, Linnaea 11: 184. $1837 . \quad$ Fig. 5 m-n

Liana, ramo cilíndrico, pubescente ou ferrugíneo-velutino com gavinhas aculeadas. Estípula 1,5 mm compr., não espinescente, triangular, caduca; estipela ausente; pecíolo 1,2-2,6 cm compr., ferrugíneo-velutino; raque 1,5-5,5 cm compr., cilíndrica, ferrugíneavelutina. Folha 5-7-foliolada, imparipinada; folíolos 3,7-5,6×1,2-2,7 cm, alternos ou opostos, oblongos ou obovados, raro elípticos, base obtusa, ápice obtuso ou acuminado, margem inteira, face adaxial glabrescente ou ferrugíneovelutina, face abaxial ferrugíneo-velutina, venação broquidódroma, concolor. Inflorescência racemo, axilar, 20-flora; pedúnculo $2 \mathrm{~cm}$ compr., velutino; raque $2,5 \mathrm{~cm}$ compr., velutina. Flor zigomorfa, pedicelada, pedicelo $0,1 \mathrm{~cm}$ compr.; cálice $5 \mathrm{~mm}$ compr., campanulado, 5laciniado, lacínios 1-2 mm compr., tomentoso externamente; corola verde, estandarte $8 \mathrm{~mm}$ compr., seríceo externamente, alas $7 \mathrm{~mm}$ compr., pétalas da carena 6-7 $\mathrm{mm}$ compr.; androceu heterodínamo, estames 10, monadelfos, 6-7 mm compr., anteras isomorfas; ovário $3 \mathrm{~mm}$ compr., seríceo, estípite $3 \mathrm{~mm}$ compr.; estilete $3 \mathrm{~mm}$ compr., curvado, barbado na base; estigma terminal, glabro. Sâmara, 5,6 cm compr., oblonga, região seminífera basal, ápice obtuso, glabrescente; semente $1,4 \times 3 \mathrm{~mm}$, obovada, enegrecida.

Material examinado: Cibrão, 17.II.2005, fr., L. C. P. Lima et al. 299 (VIC).

Material adicional examinado: BRASIL. MINAS GERAIS: Ouro Preto, estrada de Ouro Preto para São Bartolomeu, 6.XI.2005, fl., F. C. P. Garcia \& A. F. Carvalho 1098 (VIC).

A folha 5-7-foliolada, o revestimento ferrugíneo-velutino da face adaxial dos folíolos e a corola verde são característicos de Machaerium oblongifolium (Sartori \& Tozzi 1998). No Brasil está distribuída nos estados da Bahia, Minas Gerais, Rio de Janeiro e São Paulo (Lewis 1987; Sartori \& Tozzi 1998). Habita formações de mata de restinga e mata de encosta, predominantemente na faixa atlântica (Sartori \& Tozzi 1998). No PEI, ocorre em floresta estacional submontana e altimontana.
28. Poiretia punctata (Willd.) Desv., J. Bot. Agric. 1: 122. $1813 . \quad$ Fig. 5 o-p Liana, ramo estriado, hirsuto, glandular. Estípula $3 \mathrm{~mm}$ compr., ovada, caduca; estipela 3-4 mm compr., linear-lanceolada, caduca; pecíolo 1,5-4,5 cm compr., hirsuto; raque 0,5-1,2 cm compr., estriada, hirsuta. Folha 4-foliolada, paripinada; folíolos 1,6-2,9 × 1,2$2,1 \mathrm{~cm}$, opostos, obovados, base aguda, ápice obtuso, margem inteira, ambas as faces seríceas, face abaxial com pontuações translúcidas, venação broquidódroma, concolor. Inflorescência racemosa, axilar, 20-34-flora; pedúnculo 0,3-0,5 cm compr., seríceo; raque 1,2-3,7 cm compr., serícea. Flor zigomorfa, pedicelada, pedicelo $0,3-0,4 \mathrm{~cm}$ compr.; cálice $3 \mathrm{~mm}$ compr., campanulado, 5-laciniado, lacínios $1 \mathrm{~mm}$ compr., glabrescente com pontuações glandulares externamente; corola amarela, estandarte $7 \mathrm{~mm}$ compr., tomentoso com pontuações glandulares externamente, alas $9 \mathrm{~mm}$ compr., pétalas da carena $7 \mathrm{~mm}$ compr.; androceu heterodínamo, estames 10, monadelfos, 7-8 mm compr., anteras unifomes; ovário $3 \mathrm{~mm}$ compr., pubescente, séssil; estilete $6 \mathrm{~mm}$ compr., curvado, glabro; estigma terminal, glabro. Fruto não observado; semente não observada.

Material examinado: Cibrão, 17.II.2005, fl., L. C. P. Lima et al. 295 (VIC).

Poiretia punctata é diferenciada das demais Leguminosae do PEI, pelos ramos revestidos por tricomas glandulares. No Brasil, ocorre nos estados do Ceará, Pernambuco, Paraíba, Bahia, Minas Gerais, Rio de Janeiro, São Paulo e Goiás, ocupando áreas de campo, campo sujo, mata de galeria, encosta de mata e beira de estrada (Muller 1984). No PEI, foi coletada no sub-bosque de floresta estacional submontana.

29. Trifolium repens L., Sp. Pl. 2: 767. 1753.

Fig. 5 q-r

Erva prostrada, ramo estriado, glabro. Estípula 8-14 mm compr., lanceolada, persistente; estipela ausente; pecíolo 4,8-8,1 cm compr., glabro ou puberulento; raque ausente. 
Folha 3-foliolada, digitada, imparipinada; folíolos laterais simétricos; folíolo terminal 1,5-2,2 $\times 1,1-1,8 \mathrm{~cm}$, obovado, base aguda, ápice obtuso ou obcordado, margem serrilhada, face adaxial glabra, face abaxial glabra ou serícea, venação camptódroma, geralmente com uma mácula acompanhando a nervura central, concolor. Inflorescência umbelada, axilar, 16-18-flora; pedúnculo 7$14 \mathrm{~cm}$ compr., glabrescente; raque $1-1,2 \mathrm{~cm}$ diam. (incluindo o cálice), glabrescente. Flor zigomorfa, pedicelada, pedicelo 4-6 $\mathrm{mm}$ compr.; cálice $6 \mathrm{~mm}$ compr., campanulado, 5-laciniado, tubo $4 \mathrm{~mm}$ compr., lacínios 1,5$2 \mathrm{~mm}$ compr., glabro externamente; corola branca ou amarela, estandarte $10 \mathrm{~mm}$ compr., glabro externamente, alas $9 \mathrm{~mm}$ compr., pétalas da carena $8 \mathrm{~mm}$ compr.; androceu heterodínamo, estames 10, monadelfos, $6-$ $7 \mathrm{~mm}$ compr., anteras uniformes; ovário $2 \mathrm{~mm}$ compr., puberulento, estípite $1 \mathrm{~mm}$ compr.; estilete $4 \mathrm{~mm}$ compr., curvado, glabro; estigma terminal, glabro. Fruto não observado; semente não observada.

Material examinado: próximo a Fazenda do Manso, 12.XII.1990, fl., H. C. Lima et al. 4060 (OUPR); 17.XI.2005, fl., L. C. P. Lima \& A. Casazza 405 (VIC).

A folha digitada, o folíolo de margem serrilhada e a corola persistente no fruto são característicos de Trifolium repens. É uma espécie com ampla distribuição, cujo tipo de ocorrência no Brasil é incerto, logo não se sabe se é uma espécie nativa ou subespontânea (Bentham 1859). No PEI, foi coletada em área de floresta estacional altimontana.

30. Vigna peduncularis (Kunth.) Fawc. \& Rendle var. peduncularis, Fl. Jamaica 4(2): 68.1920 .

Fig. 5 s-X

Trepadeira, ramo estriado, glabrescente ou seríceo. Estípula $2 \mathrm{~mm}$ compr., lanceolada, persistente; estipela $1 \mathrm{~mm}$ compr., oblonga, persistente; pecíolo 2,1-4 cm compr., glabrescente ou seríceo; raque $0,5-1 \mathrm{~cm}$ compr., canaliculada, glabrescente ou serícea. Folha 3-foliolada, imparipinada; folíolos laterais assimétricos, folíolo terminal 1,9-5,5 $\times 1,2-1,7 \mathrm{~cm}$, lanceolado, base obtusa, ápice agudo, margem inteira, ambas as faces glabras ou glabrescentes, venação broquidódroma, concolor. Inflorescência pseudo-racemosa, axilar, 4-flora; pedúnculo $3,2-7 \mathrm{~cm}$ compr., seríceo; raque $0,4-0,9 \mathrm{~cm}$ compr., seríceo. Flor zigomorfa, pedicelada, pedicelo $0,3-0,4 \mathrm{~cm}$ compr.; cálice $6,5 \mathrm{~mm}$ compr., tubuloso, 5-laciniado, lacínios 22,5 mm compr., ciliado no ápice dos lacínios; corola lilás-arroxeada, estandarte $8 \mathrm{~mm}$ compr., glabro externamente, alas $6 \mathrm{~mm}$ compr., pétalas da carena $6 \mathrm{~mm}$ compr., contorcidas; androceu heterodínamo, estames 10 , diadelfos (9+1), 5-6 mm compr., anteras uniformes; ovário $4 \mathrm{~mm}$ compr., tomentoso, estípite $1 \mathrm{~mm}$ compr.; estilete $5 \mathrm{~mm}$ compr., espiralado, hirsuto; estigma terminal, hirsuto. Legume, $5,9-10 \times 0,2-0,5 \mathrm{~cm}$, linear, seríceo; sementes 3, $7 \mathrm{~mm}$ compr., castanhas.

Material examinado: estrada de Baixo, 12.XII.1990, fl., H. C. Lima et al. 4063 (OUPR); estrada de cima, 21.III.2005, fl. e fr., V. F. Dutra 56 (OUPR); trilha do Baú, 25.IV.2005, fl., L. C. P. Lima \& E. D. Silva 337 (VIC); 18.V.2005, fl., L. C. P. Lima \& M. P. Andrade 351 (VIC).

Segundo Maréchal et al. (1978), os folíolos lanceolados de consistência membranácea e o comprimento do estandarte (menor $2 \mathrm{~cm}$ ), são características diagnósticas desta espécie. Distribui-se da América Central até o norte da Argentina (Maréchal et al. 1978). No PEI, foi coletada em floresta estacional altimontana.

\section{Agradecimentos}

Ao CNPq, pela concessão de bolsa de mestrado à primeira autora. Ao IEF, pela estrutura física concedida. Aos curadores dos Herbários OUPR e BHCB, que gentilmente emprestaram o material solicitado. Ao Reinaldo Pinto pela confecção das ilustrações botânicas. 


\section{REFERÊNCIAS BIBLIOGRÁFICAS}

Almeida, D. G. 1953. Dalbergia frutescens (Vell.) Britton. Arquivos do Jardim Botânico do Rio de Janeiro 5: 15-34.

Azevedo, A. M. G. 1981. O gênero Desmodium Desv. no Brasil - considerações taxonômicas. Dissertação de Mestrado. Universidade Estadual de Campinas, Campinas, 315p.

Barneby, R. C. 1991. Sensitivae Censitae. A description of the genus Mimosa Linnaeus (Mimosaceae) New World. Memoirs of the New York Botanical Garden 65: 1-835.

1998. Silk tree, Guanacaste, Monkey's earring: a generic system for the synandrous Mimosaceae of the Americas. Memoirs of the New York Botanical Garden 74(3): 1-223.

Barroso, G. M. 1965. Leguminosas da Guanabara. Arquivos do Jardim Botânico do Rio de Janeiro 18: 109-177.

Barroso, G. M.; Morim, M. P.; Peixoto, A. L. \& Ichaso, C. L. F. 1999. Frutos e sementes: morfologia aplicada a sistemática de dicotiledôneas. Universidade Federal de Viçosa, Viçosa, 443p.

Barroso, G. M.; Peixoto, A. L.; Costa, C. G.; Ichaso, C. L. F.; Guimarães, E. F. \& Lima, H. C. 1991. Sistemática das angiospermas do Brasil. V.2. UFV, Viçosa. Pp. 15-100.

Bentham, G. 1859. Papilionaceae. In: Martius, C. F. P.; Endlicher, S.; Urban, I. (eds.). Flora brasiliensis 15: 1-215.

.1870. Swartzieae e Caesalpinieae. In: Martius, C. F. P.; Endlicher, S.; Urban, I. (eds.). Flora brasiliensis 15: 1-250.

1876. Mimoseae. In: Martius, C. F. P.; Endlicher, S. \& Urban, I. (eds.). Flora brasiliensis 15: 34-499.

Bortoluzzi, R. L. C.; Carvalho-Okano, R. M.; Garcia, F. C. P. \& Tozzi, A. M. G. A. 2004. Leguminosae, Papilionoideae no Parque Estadual do Rio Doce, Minas Gerais, Brasil II: árvores e arbustos escandentes. Acta Botanica Brasilica 18(1): 49-72.

Bortoluzzi, R. L. C.; Garcia, F. C. P.; CarvalhoOkano, R. M. \& Tozzi, A. M. G. A. 2003.
Leguminosae, Papilionoideae no Parque Estadual do Rio Doce, Minas Gerais, Brasil. I: trepadeiras e subarbustos. Iheringia, Série Botânica 58(1): 25-60.

Bosquetti, L. B. 2004. Caesalpinioideae (Leguminosae) no Parque Estadual do Rio Doce, Minas Gerais, Brasil. Dissertação de Mestrado. Universidade Federal de Viçosa, Viçosa, 86p.

Brandão, M. 1992. Gênero Aeschynomene L.: espécies mineiras e sua distribuição no país. Daphne 2(3): 27-46.

Burkart, A. 1970. Leguminosas-Faseólas argentinas de los géneros Mucuna, Dioclea, Camptosema. Darwiniana 16(1-2): 175-218.

1979. Flora Ilustrada CatarinenseLeguminosas, Mimosoideae, 299p.

Carvalho, A. M. 1997. A synopsis of the genus Dalbergia (Fabaceae: Dalbergieae) in Brazil. Brittonia 49(1): 87-109.

Dutra, V. F. 2005. Leguminosae Adans. nos campos rupestres do Parque Estadual do Itacolomi, Minas Gerais, Brasil: florística, preferência por habitat, aspectos reprodutivos e distribuição geográfica. Dissertação de Mestrado. Universidade Federal de Viçosa, Viçosa, 157p.

Dutra, V. F.; Messias, M. C. T. B. \& Garcia, F. C. P. 2006. Papilionoideae (Leguminosae) nos Campos Ferruginosos do Parque Estadual do Itacolomi, Minas Gerais, Brasil: florística e fenologia. Revista Brasileira de Botânica 28(3): 493-504.

Eisinger, S. M. 1987. O gênero Indigofera L. (Leguminosae-PapilionoideaeIndigofereae) no Rio Grande do Sul. Acta Botanica Brasilica 1(2): 123-140.

Fantz, P. R. 1980. Flora of Panama. Annals of the Missouri Botanical Garden 67: 582-593.

Fernandes, A. 1996. O táxon Aeschynomene no Brasil. EUFC, Fortaleza. 128p.

Fidalgo, O. \& Bononi, V. L. R. 1984. Técnicas de coleta, preservação e herborização do material botânico. Instituto de Botânica (manual 4), São Paulo, 61p. 
Filiettaz, A. M. 2002. Estudos taxonômicos de espécies de Crotalaria sect. Calycinae Wight \& Arn. (Leguminosae-PapilionoideaeCrotalarieae) no Brasil. Tese de Doutorado. Universidade Estadual de Campinas, Campinas, 145p.

Garcia, F. C. P. 1998. Relações sistemáticas e fitogeografias do gênero Inga Miller (Leguminosae, Mimosoideae, Ingeae) nas florestas da costa sul e sudeste do Brasil. Tese de Doutorado. Universidade Estadual Paulista, Rio Claro, 248p.

Guedes-Bruni, R. R.; Morim, M. P.; Lima, H. C. \& Sylvestre, L. S. 2002. Inventário Florístico. In: Sylvestre, L. S. \& Rosa, M. M. T. (orgs.). Manual Metodológico para Estudos Botânicos na Mata Atlântica. Seropédica, Rio de Janeiro. Pp. 24-49.

Harris, J. G. \& Harris, M. W. 1994. Plant identification terminology: an ilustred glossary. Spring Lake Publishing, Utah, 198p.

Holmgren, P. K.; Holmgren, N. H. \& Barnet, L. C. 1990. Index Herbariorum of the world. 8 ed. The NewYork Botanical Gardens, Kew, 693p.

Ildis. 2005. International Legumes Database \& Information Service. Disponível http:// ildis.org. Acesso em 8 de dezembro 2005.

Irwin, H. S. \& Barneby, R. C. 1982. The American Cassiinae - A synoptical revision of Leguminosae - Tribe Cassieae subtribe Cassiinae in the New World. Memoirs of the New York Botanical Garden 35: 1-918.

Lewis, G. P. 1987. Legumes of Bahia. Royal Botanic Gardens, Kew, 369p.

Lewis, G.; Schire, B.; Mackinder, B. \& Lock, M. 2005. Legumes of the World. The Royal Botanic Gardens, Kew, 577p.

Lima. H. C. 2000. Leguminosas arbóreas da Mata Atlântica - uma análise da riqueza, padrões de distribuição geográfica e similaridades florísticas em remanescentes florestais do estado do Rio de Janeiro. Tese de Doutorado. Universidade Federal do Rio de Janeiro, Rio de Janeiro, 122p.
Lima, H. C.; Correia, C. M. B. \& Farias, D. S. 1994. Leguminosae. In: Lima, M. P. M. \& Guedes-Bruni, R. R. (orgs.). ReservaEcológica de Macaé de Cima, Nova Friburgo, RJ: Aspectos florísticos das espécies vasculares. V.1. Jardim Botânico do Rio de Janeiro, Rio de Janeiro. Pp. 167-228.

Lima, L. C. P.; Sartori, A. L. B. \& Pott, V. J. 2006. Aeschynomene (LeguminosaePapilionoideae-Aeschynomeneae) no estado de Mato Grosso do Sul, Brasil. Hoehnea 33(4): 419-453.

Lorenzi, H. 1982. Plantas daninhas do Brasil: terrestres, aquáticas, parasitas, tóxicas e medicinais. Ed. Plantarum, Nova Odessa, 425p.

Maréchal, R.; Mascherpa, J. M. \& Stainer, F. 1978. Étude taxonomique d'un grupe complex d' espéces des genes Phaseolus et Vigna (Papilionaceae) sur la base de dornnées morphologiques et polliniques, traitées par 1'analyse informatique. Boissiera 28: 1-273.

Martins, C. S. 2000. Caracterização física e fitogeográfica de Minas Gerais. In: Mendonça, M. P. \& Lins, L. V. (eds.). Lista vermelha das espécies ameaçadas de extinção da Flora de Minas Gerais. Fundação Biodiversitas, Zoo-Botânica, Belo-Horizonte. Pp. 35-43.

Mendonça, R. C.; Felfili, J. M.; Walter, B. M. T.; Silva Jr., M. C.; Rezende, A. V.; Filgueiras, T. S. \& Nogueira, P. E. 1998. Flora vascular do cerrado. In: Sano, S. M. \& Almeida, S. P. (eds.). Cerrado: Ambiente e Flora. Embrapa-CPAC, Planaltina. Pp. 289-539.

Mendonça-Filho, C. V. 1996. Braúna, angico, jacarandá e outras leguminosas de Mata Atlântica: Estação Biológica de Caratinga, Minas Gerais. Fundação Botânica Margaret Mee; Fundação Biodoiversitas, Belo Horizonte, 100p.

Messias, M. C. T. B.; Dias, S. J. L.; Roschel, M. B.; Souza, H. C.; Silva, J. L.; Matos \& A. V. M. 1997. Levantamento florístico 
das matas e distribuição de algumas espécies endêmicas da região na área do Parque do Itacolomi. UFOP/BIRD/IEFPROFLORESTA. Relatório Técnico (polígrafo), Ouro Preto, 151p.

Miotto, S. T. S. 1987a. Os gêneros Centrosema (DC.) Benth. e Clitoria L. (Leguminosae, Faboideae) no Rio Grande do Sul. Iheringia, série Botânica 36: 15-39.

1987b. Os gêneros Canavalia (DC.) e Dioclea H.B.K. (Leguminosae, Faboideae) no Rio Grande do Sul. Iheringia, série Botânica 36: 41-55.

Muller, C. 1984. Revisão taxonômica do gênero Poiretia Vent. (Leguminosae) para o Brasil. Dissertação de Mestrado. Universidade Estadual de Campinas, Campinas.

Nobre, A. V. M.; Sartori, A. L. B. \& Rezende, U.M. (no prelo). As espécies de Desmodium Desv. (LeguminosaePapilionoideae-Desmodieae) ocorrentes em Mato Grosso do Sul. Revista Iheringia, Série Botânica.

Nunes, S. R. D. F. S. 2003. As Mimosoideae (Leguminosae) no Parque Estadual do Rio Doce, Minas Gerais, Brasil. Dissertação de Mestrado. Universidade Federal de Viçosa, Viçosa, 106p.

Oliveira-Filho, A. T. \& Fontes, M. A. L. 2000. Patterns of floristic differentiation among Atlantic forests in south-eastern Brazil, and influence of climate. Biotropica 32(4b): 793-810.

Oliveira-Filho, A. T.; Vilelas, E. A.; Gavilanes, M. L. \& Carvalho, D. A. 1994. Comparison of the flora and soils of six areas of Montane Semideciduous Forest in southern Minas Gerais, Brazil. Endinburgh Journal of Botany 51(3): 355-389.

Pennington, T. D. 1997. The genus Inga: Botany. Royal Botanic Gardens, Kew, 844p.

Peron, M. V. 1989. Listagem preliminar da flora fanerogâmica dos campos rupestres do Parque Estadual do Itacolomi-Ouro Preto/ Mariana, MG. Rodriguesia 67(41): 63-69.
Polhil, R. M. 1982. Crotalaria in África and Madagascar. Royal Botanic Gardens, Kew, 369p.

Queiroz, L. P. 1999. Sistemática e filogenia do gênero Camptosema W.J.Hook. \& Arn. (Leguminosae: Papilionoideae: Phaseoleae). Tese de Doutorado. Universidade de São Paulo, São Paulo, 259p. 2004. Flora de Grão-Mogol, Minas Gerais: Leguminosae. Boletim de Botânica da Universidade de São Paulo 22(2): 213-265.

Radford, A. E.; Dickison, W. C.; Massey, J. R. \& Bell, C. R. 1974. Vascular plant systematics. Harper \& Row, New York, 891p.

Ribeiro, J. F. 1998. Cerrado: Matas de galeria. Embrapa-CPAC, Planaltina, 164p.

Rizzini, C. T. 1997. Tratado de fitogeografia do Brasil. Âmbito Cultural Edições Ltda, Rio de Janeiro, 747p.

Rudd, V. E. 1955. The American species of Aeschynomene. Bulletin of the United States National Herbarium 32: 1-172. 1958. A revision of the genus Chaetocalyx. Contributions from the National Herbarium 32(3): 207-245.

Sartori, A. L. B. \& Tozzi, A. M. G. A. 1998. As espécies de Machaerium Pers. (Leguminosae-PapilioinoideaeDalbergieae) ocorrentes no estado de São Paulo. Revista Brasileira de Botânica 21(3): 211-246.

Silva, A. F. 2000. Floresta Atlântica. In: Mendonça, M. P. \& Lins, L. V. (eds.). Lista vermelha das espécies ameaçadas de extinção da Flora de Minas Gerais. Fundação Biodiversitas, Zoo-Botânica, Belo-Horizonte. Pp. 45-53.

Silva, A. S. L. 1990. Contribuição ao estudo sistemático das espécies do gênero Acacia Mill. (Leguminosae-Mimosoideae), ocorrentes na Amazônia brasileira. Boletim Museu Paraense Emílio Goeldi Série Botânica 6(2): 159-226. 
Tamashiro, J. Y. 1989. Estudos taxonômicos morfológicos do gênero Piptadenia, sensu Bentham no sudeste do Brasil. Avaliação das modificações taxonômicas recentemente propostas. Dissertação de Mestrado. Universidade Estadual de Campinas, Campinas, 99p.

Vaz, A. M. F. 1995. Trepadeiras do gênero Bauhinia (Caesalpiniaceae) no estado do Rio de Janeiro. Pesquisa Botânica 44: 95-114.
Vaz, A. M. S. F. \& Tozzi, A. M. G. A. 2003. Bauhinia ser. Cansenia (Leguminosae: Caesalpinioideae) no Brasil. Rodriguésia 54(83): 55-143.

Veloso, H. P; Rangel-Filho, A. L. R.; Lima, J. C. A. 1991. Classificação da vegetação brasileira, adaptada a um sistema universal. IBGE, Departamento de Recursos Naturais e Ambientais, Rio de Janeiro, 123p. 